This item was submitted to Loughborough's Research Repository by the author.

Items in Figshare are protected by copyright, with all rights reserved, unless otherwise indicated.

\title{
A review of performance degradation and failure modes for hydrogen-fuelled polymer electrolyte fuel cells
}

PLEASE CITE THE PUBLISHED VERSION

PUBLISHER

(C) IMechE / Professional Engineering Publishing

LICENCE

CC BY-NC-ND 4.0

REPOSITORY RECORD

Rama, Pratap, Rui Chen, and J.D. Andrews. 2008. "A Review of Performance Degradation and Failure Modes for Hydrogen-fuelled Polymer Electrolyte Fuel Cells”. figshare. https://hdl.handle.net/2134/3948. 
This item was submitted to Loughborough's Institutional Repository (https://dspace.lboro.ac.uk/) by the author and is made available under the following Creative Commons Licence conditions.

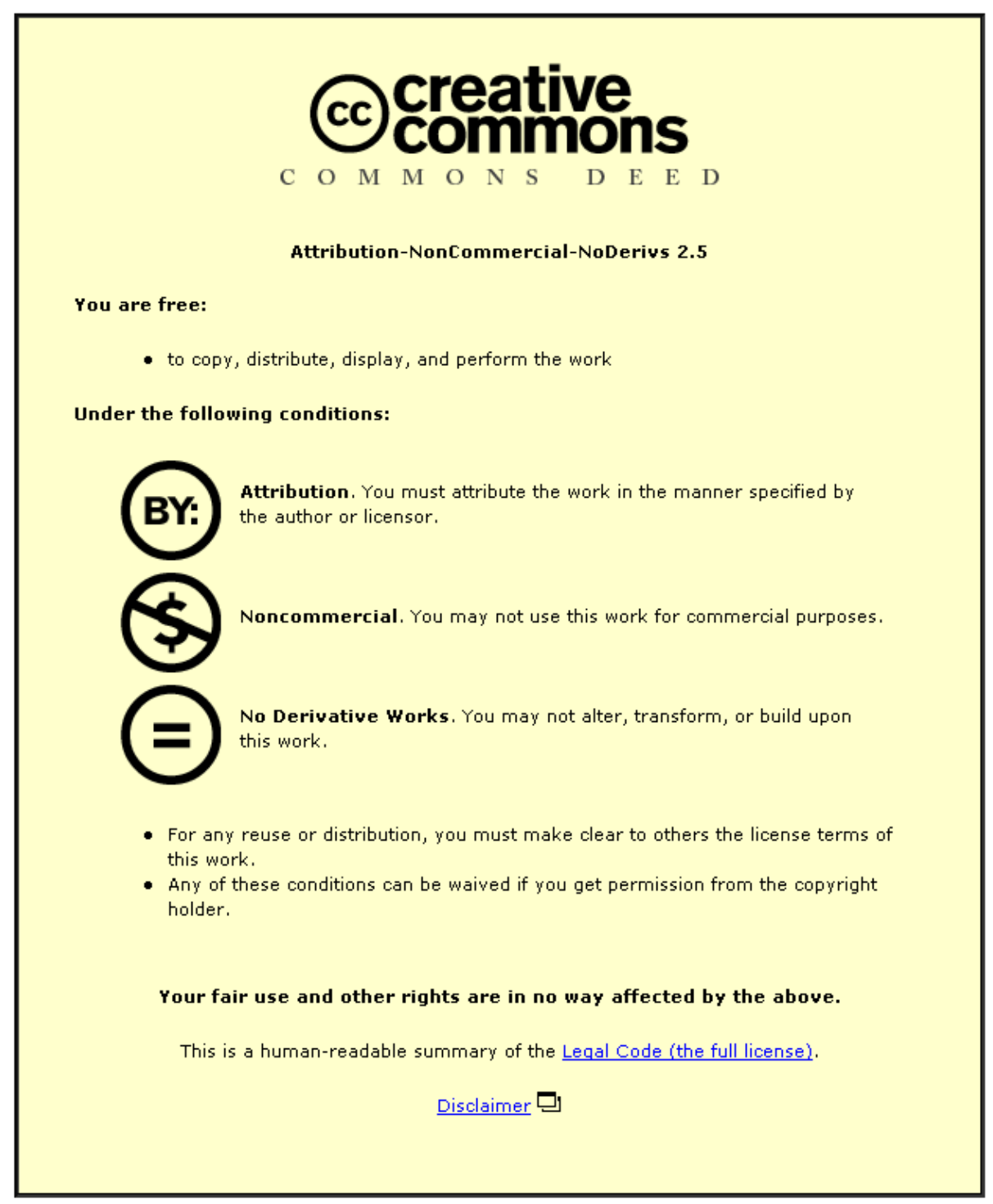

For the full text of this licence, please go to: http://creativecommons.org/licenses/by-nc-nd/2.5/ 


\title{
A review of performance degradation and failure modes for hydrogen-fuelled polymer electrolyte fuel cells
}

\author{
P Rama*, R Chen, and J Andrews \\ Department of Aeronautical and Automotive Engineering, Loughborough University, Loughborough, Leicestershire, UK
}

The manuscript was received on 7 March 2008 and was accepted after revision for publication on 22 April 2008.

DOI: 10.1243/09576509JPE603

\begin{abstract}
A qualitative account of the causes and effects of performance degradation and failure in hydrogen-fuelled polymer electrolyte fuel cells (PEFCs) is given in the present review. The purpose of the review is to establish a backbone understanding of the phenomenological processes that occur within the PEFC, how they interact, how they are influenced through elements of design, manufacturing and operation, and ultimately how they result in performance degradation and cell failure. In the current work, 22 common faults are identified which are induced by 48 frequent causes. The major PEFC components considered here that are susceptible to faults are the polymer electrolyte-based membrane, the anode and cathode catalyst layers, gas diffusion and microporous layers, seals and the bipolar plate. Faults pertaining to these components can cause irreversible increases in activation, mass transportation, ohmic and fuel efficiency losses, or indeed cause catastrophic cell failure.
\end{abstract}

Keywords: polymer electrolyte fuel cells, hydrogen, reliability, performance degradation, failure

\section{INTRODUCTION}

Escalating concerns regarding the impact that conventional methods of energy conversion are having on the environment and on global economics have in recent times progressively fuelled research and development into alternative technologies. One technology that is potentially independent of fossil fuels and suited to a wide range of applications from portable to transport and stationary systems is the polymer electrolyte fuel cell (PEFC). PEFCs have been the focus of significant research and development for over five decades. The electrochemical energy conversion device inherently mitigates the need to combust reactant gases directly which thereby prevents it from being restricted to the Carnot efficiency. PEFCs operate on a hydrogen oxidation and oxygen reduction principal to generate electrical power and water as a by-product. Single cells themselves can be 'stacked' to meet the power demands of the target application.

\footnotetext{
${ }^{*}$ Corresponding author: Department of Aeronautical and Automotive Engineering, Stewart Miller Building, Loughborough University, Loughborough, Leicestershire LE11 3TU, UK. email: p.rama@lboro.ac.uk
}

Each type of PEFC application will have its own set of requirements. During the course of research and development so far, this has resulted in a vast multitude of materials, designs, manufacturing techniques, and considerations for the different components of the cell $[\mathbf{1}-\mathbf{3}]$. These variations also reflect the fact that there are indeed a multitude of factors that govern the performance of the PEFC, all of which have some element of physical design or operation associated to it, that can be altered to improve an aspect of cell performance.

Variations in operating modes and general cell design according to application means that performance degradation and failure mechanisms are also likely to change according to application. Automotive fuel cells, for example, are likely to operate with neat hydrogen under load-following or load-levelled modes and are expected to withstand variations in environmental conditions, particularly in the context of temperature and atmospheric composition. In addition, they are also required to survive over the course of their expected operational lifetimes, i.e. around $5500 \mathrm{~h}$, while undergoing as many as 30000 startup/shutdown cycles [4]. PEFCs for stationary applications would not be subjected to as many startup/shutdown cycles; however, they would be expected to survive up to 
$10000-40000 \mathrm{~h}$ of operation while maintaining a tolerance to fuel impurities in the reformate feed. The current review covers aspects that govern performance degradation and failure that are potentially relevant to all types of applications.

Failure and reliability can be understood in the context of the following definitions [5]; failure is an end-user detectable and verifiable loss of product functionality resulting in an unscheduled repair and/or replacement to restore the lost functionality; reliability reflects the conditional probability at a given confidence level that the system will perform its intended functions without failure for a specified time period when operated under prescribed usage and environmental conditions. Key technology indicators such as technology readiness level (TRL) and manufacturing readiness level (MRL) are intrinsically governed by failure and reliability [6]. In the context of fuel cells, failure can occur as a consequence of gradual processes, in which certain operating conditions and operational routines cause a systematic degradation of structural and electro-kinetic properties of PEFC assemblies and culminate in the loss of performance below threshold values. The performance of a PEFC is characterized by one of four loss mechanisms: (a) ohmic losses; (b) activation losses; (c) mass transportation losses; and (d) fuel efficiency losses. Some degradation mechanisms can contribute towards multiple loss mechanisms. They can also lead to the final form of user-detectable loss: (e) catastrophic cell failure. The current review aims to provide a structured understanding of the general factors that govern the reliability and safety of hydrogen-fuelled PEFCs by considering the cause and effect of the underlying phenomenological mechanisms in the context of performance degradation and failure $[\mathbf{7}, \mathbf{8}]$.

\section{MECHANISMS OF PERFORMANCE LOSS AND DEGRADATION}

Activation losses are attributed to the slowness of reactions occurring in the fuel cell electrodes. The anode kinetics are much faster than the cathode kinetics and it is the cathodic oxygen reduction process that largely contributes to the overall activation loss. Activation losses can increase during the course of operation if the electrochemically active surface area (EASA) reduces in the fuel cell catalyst layers. Significant factors affecting performance in the catalyst layer include material composition, geometric structure and impurity concentrations in the reactant feeds.

Mass transportation losses occur when there is a change in the concentration of a reactant gas on the surface of an electrode. At high current densities, since hydrogen oxidation and oxygen reduction hasten, there can be a general reduction in the concentration profile of the gases along the length of a reactant supply channel. The hydrogen oxidation and oxygen reduction process gives rise to the release of electrical energy, heat energy, and water. The water forms at the cathode side, some of which is retained by the electrolyte membrane and enhances its proton conductivity. Excess water has to be expelled from the cathode in order to prevent liquid water formation and accumulation, which can impede pathways for the transport of oxygen to the catalyst sites. At high current densities, where water formation correspondingly hastens, it can become difficult to remove the water from the cathode, which can cause a drastic loss or 'polarization' in cell performance. It is likely that as water begins to accumulate and condense with increasing current density, flows in the porous regions and the channels of the bipolar plate (BPP) will transition from single phase (gas) to two phase (gas and liquid). This can cause a change both in the local concentration and in the general concentration profile of oxygen along the length of a flow path.

Ohmic losses can be attributed to the ionconducting properties of the different elements of the single cell. The electrolyte-based membrane is the central proton conducting part of the cell, which connects the matrix dispersion of electrolyte in the two catalyst layers. Low-temperature PEFCs employ perflourinated sulphonic acid (PFSA) membranes and operate up to around $110^{\circ} \mathrm{C}$. Higher-temperature PEFCs can employ phosphoric-acid-doped polybenzimidazole (PBI) membranes and can operate up to $200{ }^{\circ} \mathrm{C}$. The PFSA polymer electrolyte material contains end groups that have a fixed ionic charge, for example, $\mathrm{SO}_{3}^{-}$end groups, and excludes anions by electrostatic repulsion. Nafion is an example of a thermally stable PFSA membrane, which does not decompose until $280^{\circ} \mathrm{C}$ [9]. The mobility of protons is of primary interest, which depends on its attraction to the $\mathrm{SO}_{3}^{-}$ charge groups. In the dry state, the attraction is sufficiently high to render protons immobile and therefore proton conductivity is correspondingly low. The polymer electrolyte material is generally hydrophilic due to the sulphonate side chains, which allows the uptake of water [10]. Under hydrated conditions, the ensuing mechanism that dominates proton mobility is commonly termed Grotthus hopping. Here, proton transfer occurs from an $\mathrm{H}_{3} \mathrm{O}^{+}$molecule to a neighbouring $\mathrm{H}_{2} \mathrm{O}$ molecule, usually followed by a transfer of a different hydrogen atom of the newly formed $\mathrm{H}_{3} \mathrm{O}^{+}$to another $\mathrm{H}_{2} \mathrm{O}$ neighbour [11]. In order to ensure proton conductivity and to limit the associated ohmic loss, a threshold matrix of water also has to be maintained [12]. Ensuring that the membrane is sufficiently hydrated is therefore an inherent objective of fuel cells employing PFSA-based membranes. One way of maintaining membrane hydration is by using thin 
membranes $(\leqslant 50 \mu \mathrm{m})$. Conceptually, this limits the transport path of water within the membrane from cathode to anode and thereby allows a high and uniform water content distribution to be maintained. This, in turn, results in high proton conductivity. As such, thin membranes are commonly used in automotive applications to lessen the demands on external humidification. Fundamentally, PBI membranes do not require comparably high levels of humidity from the outset in order to achieve proton conductivities comparable to PFSA membranes. The focus of this review is on longstanding PFSA-based membranes, for which the mechanisms that govern its performance have been more extensively reported in the literature.

Following on from proton conductivity, electron conductivity is a significant issue for PEFCs. The electron conducting parts of the PEFC have finite resistances that are dependent upon cell operating temperature and the compaction force applied to a cell. The gas diffusion layers (GDLs) maintain an interfacial contact between the anodic and cathodic catalyst layers and the BPP, which thereby provides pathways for electron transfer. Good bulk electrical conductivity, minimal surface corrosion and good electrical contact between these layers can minimize ohmic losses.

Fuel efficiency losses can be explained in the context of fuel crossover. As hydrogen passes through the anode GDL and enters the anode catalyst layer, it is possible for some of the hydrogen to permeate straight through the polymer membrane, forgoing the electro-oxidation process. Consequently, it reacts directly with oxygen in the cathode catalyst layer and amounts to a proportion of spent fuel that does not contribute towards the electrical energy harnessed from the cell. This is described as an efficiency loss. It is of course possible for oxygen to permeate the polymer membrane from the opposite direction and directly react with hydrogen in the anode catalyst layer. Fuel crossover is not entirely avoidable since the polymer membrane is an expandable, permeable material and susceptible to the enlargement of internal pores that correspondingly give way to gas transport. The mechanical state and structure of the polymer membrane is the largest factor governing the amount of fuel crossover; thinner membranes can be susceptible to higher crossover rates than thicker membranes due to the shorter transport paths, depending on the operating conditions.

The above provides an indicative outline of the loss mechanisms encountered in PEFCs that govern performance degradation and failure. The current review provides an account of how each of these loss mechanisms could be affected by phenomenological processes that are induced by elements of design, manufacture, testing or operation. The review also discusses how these issues are being addressed through technological advancements.

\section{ACTIVATION LOSSES}

\subsection{Platinum agglomeration}

In order to maximize the EASA in the anodic and cathodic catalyst layers, the catalyst is applied as fine and widely dispersed nanoparticles on the surface of a supporting particle [10]. Typically, the catalyst is platinum or platinum alloyed with ruthenium or chromium for example, and the larger supporting particle is commonly carbon-based. Recent studies have shown that within $2000 \mathrm{~h}$ of operation, it is possible for the metal catalyst to undergo morphological change in the form of catalytic agglomeration and/or ripening [13]. This leads on to a gradual decrease in the EASA. Although agglomeration is observed for both anode and cathode catalyst layers, it is usually the cathodic particles that undergo more extensive agglomeration, where there is an increased presence of liquid water and which facilitates primary corrosion [14]. Repetitive on/off load cycles for PEFCs can also cause platinum sintering; residual hydrogen can induce a high voltage equivalent to open-circuit voltage to the cathode, causing the sintering to occur [15]. This can be mitigated by purging the anode channel with air. Loss of EASA due to possible agglomeration has also been observed for un-humidified PEFCs operating at a higher temperature of $150^{\circ} \mathrm{C}$ in PBI membranes [16].

\subsection{Platinum migration}

Another mechanism for the loss of EASA could be attributed to the movement of platinum. When the PEFC is operated through hydrogen-air open circuit to air-air open circuit, platinum can become quite soluble and consequently liable to transportation through adjacent layers [17]. Loss of platinum correspondingly compromises the EASA. Such phenomenon can also be accompanied by an apparent migration of platinum. Migration of metal catalyst particles in both the anode and cathode catalyst layers in PEFCs has been observed, moving towards the interface between the catalyst layer and the membrane [14]. It is notable that the migration of platinum from the cathode catalyst layer to the anode has also been observed in phosphoric acid fuel cells (PAFCs) [18].

\subsection{Exposure to subzero operating conditions}

Exposure to subzero operating environments is also known to compromise the EASA. The repetitive freezing and melting of water in the catalyst layer is likely to deform the structure of the catalyst layers by increasing the pore size and reducing the EASA [19]. 


\subsection{Atmospheric contaminants}

Activation losses at the anode and the cathode can significantly increase due to reactant contamination and due to the leaching of contaminants; catalytic contamination can occur due to both air pollutants and fuel impurities. The presence of excess liquid water exacerbates the effects of contamination, which can act to transport leached impurities within the cell [20]. Impurities are thereby deposited on the catalyst sites, compromising the EASA on either or both electrodes.

Air impurities such as $\mathrm{NO}_{2}, \mathrm{SO}_{2}$, and $\mathrm{H}_{2} \mathrm{~S}$ have been found to have a negative impact upon cell performance due to their adsorption on platinum catalyst sites [21]. It has been reported that with low concentrations of $\mathrm{NO}_{2}$ and $\mathrm{SO}_{2}$, i.e. 0.4 and $0.5 \mathrm{ppm}$, respectively, the effects of contamination on cell performance can be reversed if the cathode is subsequently fed with neat air [22]. For higher concentrations, i.e. $1-5 \mathrm{ppm}$ of either $\mathrm{NO}_{2}$ or $\mathrm{SO}_{2}$, cyclic voltammetry is required to fully recover the cathode $[9,23]$. Exposure to $\mathrm{SO}_{2}$ and $\mathrm{H}_{2} \mathrm{~S}$ appear to lead on to the formation of two sulphur species, one of which adsorbs strongly on the platinum sites. In either case, cyclic voltammetry is required to oxidize the sulphur adsorbed [9].

\subsection{Fuel contaminants}

Operating PEFCs on a hydrocarbon reformate could expose the anode catalyst layer to $\mathrm{CO}$ in the concentration range of 10-100 ppm [24]. Reformation of $\mathrm{CH}_{4}$, for example, can yield a hydrogen-rich fuel feed with 80 per cent $\mathrm{H}_{2}$ and 20 per cent $\mathrm{CO}_{2}$ and $\mathrm{CO}$ in the mentioned concentrations [25]. The $\mathrm{CO}_{2}$ can lead on to the formation of additional $\mathrm{CO}$ in the anode catalyst layer either through a reverse water-gas shift reaction or through the electro-reduction of $\mathrm{CO}_{2}[\mathbf{1 3}]$. $\mathrm{CO}$ is mainly problematic as it will adsorb onto platinum more strongly than $\mathrm{H}_{2}$, thereby compromising the EASA for hydrogen oxidation. The CO in the fuel feed can also cross-over through the membrane to the cathode catalyst layer $[\mathbf{2 6}, \mathbf{2 7}]$ and can also be present in air. CO contamination can therefore also compromise the EASA for oxygen reduction in the cathode catalyst layer, reducing cathode performance. $\mathrm{CO}$ coverage can be reduced if the platinum catalyst is alloyed with $\mathrm{Ru}$ and $\mathrm{Sn}$ to give $\mathrm{PtRu}$ and $\mathrm{Pt}_{3} \mathrm{Sn}[\mathbf{2 8}$. Other methods used with alloying include ensuring that the saturated vapour pressure of the fuel feed is maintained during operation, by reducing the thickness of the catalyst layer [29], and by elevating the cell temperature from 80 to $\sim 120^{\circ} \mathrm{C}$, which improves the activity of the catalyst layer for hydrogen oxidation [30]. In another method, oxygen is bled into the $\mathrm{H}_{2}$ feed in order to oxidize $\mathrm{CO}$ to $\mathrm{CO}_{2}$ before it reaches the anode catalyst layer [31]. A more recent method includes the use of a 'reconfiguration anode', where a catalytic material which uses cobalt, iron, and copper is applied to the gas-facing side of the anode GDL to oxidize the $\mathrm{CO}$ in the fuel feed before it permeates into the anode catalyst layer [32]. A comprehensive review of articles discussing PEFC contamination to date has been carried out by Cheng et al. [33].

\subsection{Carbon corrosion}

Altering the structural composition and material use can improve the performance and stability of the catalyst layers. Nafion and catalyst distributions can be applied non-uniformly to favourably maximize the proton transport and porosity in the opposing regions of greatest ion flux and gaseous flux, respectively [34-37]. Catalytic supports can be favourably chosen for minimized oxidation rates. Carbon corrosion is a significant issue for fuel cells and can occur during fuel starvation when there is only partial coverage of hydrogen on the catalyst sites and during localized flooding [38, 39]. Such conditions can be induced or exacerbated during cyclic operation. If a single cell has insufficient fuel to support the current drawn, carbon can corrode to support the current above that provided by the fuel $[\mathbf{3 8}]$. The standard potential for the corrosion of carbon is $0.207 \mathrm{~V}$. When the anode potential is below $0.207 \mathrm{~V}$, fuel is consumed to drive the current. When the anode potential rises above $0.207 \mathrm{~V}$, carbon corrosion in the anode catalyst layer occurs to supply protons to support the current [38]. Platinum agglomeration can also be instigated as a consequence of a loss of catalytic support during carbon corrosion [40]. The chemical equation for carbon corrosion is as follows [38]

$$
\mathrm{C}+2 \mathrm{H}_{2} \mathrm{O}=\mathrm{CO}_{2}+4 \mathrm{H}^{+}+4 \mathrm{e}^{-}
$$

It has been shown, for example, that while XC72 carbon black reacts more slowly than Black Pearls (BP) 2000, they both become less stable supports under humidified fuel-cell operating conditions in comparison to dry conditions [41]. Although humidification is necessary for most PEFC designs to reduce the resistance to proton transfer in the polymer membrane, humidifying the cathodic reactant supply up to 60 per cent will also improve catalytic activity due to its impact on the rate-determining step of the oxygen reduction reaction (ORR) [42]. For low-temperature automotive PEFC stacks, for example, some level of humidification is invariably unavoidable. Graphitization of carbon supports is suggested as one method to improve thermal stability under such conditions if a high surface area for the supports can be maintained [41]. Operating under fixed current densities and flowrates also avoids the mentioned processes that incur carbon corrosion [36]. One alternative to carbon-black 
supported platinum catalysts are multi-walled carbon nanotube supported platinum (Pt/CNT) catalysts, which through accelerated durability tests have shown that they are more resistant to platinum sintering. This is due to the stability of CNTs, which possess a higher resistance to electrochemical oxidation than carbon black $[43]$.

\subsection{Chemical degradation of silicone seals}

Another reported form of catalytic contamination can be caused by the chemical degradation of sealing material used in the fuel cell stack. Typically, seals in fuel cell stacks are made of silicone and serve to avoid mixing of hydrogen and oxygen. The acidic character of the polymer electrolyte membrane along with the thermal stressing of the silicone seal can cause it to degrade chemically but without compromising its mechanical functionality [44]. The process is marked by yellow colouration. The products of the silicone reaction occur at both the anode and cathode side, but try to move towards the cathode due to the electric field. PFSA membranes have been found to be impermeable to the products, and so cause the products to accumulate in the catalyst layers. Schulze et al. [44] reported that in the cathode catalyst layer, the decomposition products react with catalyst to form particles containing silicone, oxygen, and platinum.

\section{MASS TRANSPORTATION LOSSES}

\subsection{Cell flooding}

Impedance to the transport of reactants to the catalyst sites results in an increase of mass transportation losses. It can manifest itself in several different ways, but results in the loss of gas-phase permeability in the porous layers of the cell. It occurs mainly in the cathode side of the cell, due to the formation of liquid water, which restricts the transport of oxygen. This compromises the partial pressure and hence the local oxygen concentration on the cathode catalyst sites. It propagates from the cathode catalyst layer and can lead to flooding in the GDL and the cathode reactant supply channel. Water management has therefore been the focus of a significant number of research groups and has resulted in a multitude of design and operating strategies aimed at mitigating mass transportation losses. Liquid water in the flow fields can be carried away if the channel flowrates are sufficiently high. Pressure drops along straight sections and particularly around flow field bends, however, can lead to water accumulation, which subsequently leads to the clogging-up of channels and therefore potentially to cell shut-down [45].
Pressure drops along a single channel are governed by the physical characteristics of the channel and the physical characteristics of the fluid. The most relevant physical characteristics of the channel include its length and cross-sectional geometry; the number, closeness, abruptness, and geometry of channel bends and the hydrophobicity of the BPP surface. The characteristics of the fluid are reflected by the Reynolds number $(R e)[46,47]$. Flows that have low Reynolds numbers $(R e<50)$ are mainly dominated by viscous forces and thereby susceptible to pressure losses induced by skin friction. Flows with higher Reynolds numbers $(R e>200)$, are susceptible to flow separation particularly when the flow direction is abruptly changed. Flow separation in the vicinity of sharp corners of flow-field bends leads to the formation of vortices, which also results in pressure losses. Vortices can also form in the same manner in the vicinity of inlet manifolds [48]. The introduction of finite curvature ratios for $90^{\circ}$ bends can assist in maintaining laminar flow [35]. In addition, in order to allow separating flows to become laminar again, it is necessary to optimize the length of the straight section immediately downstream of the bend.

In the general case, pressure losses along single channels can be minimized if the overall flow-field path length is kept short and if the number and abruptness of bends are minimized. Recent studies have highlighted that uniform flows with typically small pressure drops can be established particularly for flow fields with straight, parallel channels [49] and for serpentine channels that have shorter path lengths and larger numbers of multiple channels rather than those that have longer path lengths and fewer channels within the same cell area [50]. Such measures can ensure that the channels remain pressurized along their entire lengths and reduce the chance of flooding whereby high upstream pressures and low downstream pressures are established, causing liquid water to be pushed down and accumulate in downstream regions of the flow fields [51]. In general, liquid water has a tendency to accumulate in regions where the gas-phase flow becomes stagnant, particularly in abrupt $180^{\circ}$ bends often seen in serpentine flow fields [52-54].

Interdigitated flow fields could be used over conventional gas distributors to improve oxygen distribution to the cathode catalyst layer and water removal by adding forced convection to gas diffusion to drive transport in the porous layers [55]. Forced convection is induced by decoupling the direct path between inlet and exit flow fields on both sides of the BPP design. Under certain conditions, interdigitated flow fields can also yield reductions in fuel consumption rates without loss in performance compared to conventional flow field designs [56]. In the context of PEFC stacks, interdigitated flow fields can also induce 
unbalanced pressure drops between cells. The concept is still undergoing development [57-69].

Counterflow configurations have shown that orienting the reactant flows to pass through opposite-sided inlets can allow for better internal humidification of the cell $[\mathbf{7 0}, \mathbf{7 1}]$. The high water content in the anode inlet feed can be used to humidify the membrane through electro-osmotic drag from the anode to the dry cathode, whereas the cathode inlet is adjacent to the drier anode exit feed, which allows for membrane hydration through diffusion and convention, driven from the cathode side. Counterflow configurations are common for automotive fuel cell stacks [72] and depending upon the operating strategy it is possible to delay the onset of flooding.

If water can be generated within the membrane for humidification, it would be possible to reduce the extent to which the inlet reactant gases need to be humidified. This would naturally suppress the onset of two-phase flow and cell flooding, and assist in simplifying the system design. As such, the dispersion of platinum particles within the membrane has been explored [73, 74]. Here, water would be generated within the membrane by virtue of the recombination of hydrogen and oxygen on catalyst sites. The concept therefore relies upon the permeation of hydrogen and oxygen through the membrane region. The limitation of this method is that the platinum dispersions are susceptible to forming electron-conducting networks, causing short circuits [75]. Recent re-developments have focused on membranes consisting of one middle layer of Nafion containing dispersions of Pt/CNT with two outer layers of Nafion [75]. The entire membrane assembly can be as thin as $25 \mu \mathrm{m}$. Reported results show that up to 90 per cent of the performance obtained with humidified reactants can be obtained by such self-humidifying membranes with dry reactants [75]. Another example is of silicone oxidesupported platinum catalyst dispersed within protected three-layer sulfonated poly(ether ether ketone) (SPEEK)/PTFE/Nafion matrix membranes [76]. At present, though, self-humidification is not a standard concept.

Along with the literature reported above on the various means of mitigating mass transportation losses, numerous patents have been filed related to improved water management schemes [77-82].

\subsection{Hydrophobicity of porous layers}

Liquid water transportation and removal can be facilitated by treating porous layers with hydrophobic material, commonly polytetrafluoroethylene (PTFE) or fluorinated ethylene propylene (FEP). The hydrophobicity of a surface is reflected through the contact angle that a water droplet makes on the surface of the material; a contact angle less than $90^{\circ}$ reflects a hydrophilic surface, while that greater than $90^{\circ}$ reflects a hydrophobic surface.

Water transport can be managed through the use of a microporous layer (MPL). The MPL is situated between the cathode catalyst layer and the GDL. It is highly hydrophobic and acts to transport liquid water away from the cathode GDL in the direction of the anode via the membrane, thereby delaying flooding effects in the cathode and simultaneously hydrating the membrane layer [83-87]. Because the MPL lessens the sensitivity of the catalyst layer to flooding, this thereby allows thinner catalyst layers to be used [88]. In addition, a bifunctional hydrophobic and hydrophilic pore structure can simultaneously facilitate both gasphase and liquid-phase transport, respectively. Such pore structures can be achieved with composite carbon black loaded to around $0.5 \mathrm{mg} / \mathrm{cm}^{2}$ with a PTFE content of $30 \mathrm{wt} \%$ [89].

The GDL is also usually treated with PTFE. A higher PTFE content can also help to preserve the porous structure of the GDL by increasing the material rigidity [90]; however, it can also compromise the electrical conductivity of the GDL [91] and excessive coating can lead to high levels of flooding [88]. Also, it has been shown that for GDLs that are made up of graphite fibres, the hydrophobic polymer tends to localize on the surface regions on treatment; large numbers of surface pores made by intersecting fibres will be blocked by thin polymer films, rendering the bulk of the interior less hydrophobic [92]. It has also been shown that the contact angle of treated GDLs can reduce with temperature [92].

Mechanical and electrochemical degradation of PTFE in GDLs has also been reported $[92,93]$. Operating conditions that induce thermal cycles in the fuel cell stack that result in a loss of hydrophobicity can therefore make water removal more difficult. It can also cause the polymer to delaminate, thereby deteriorating the hydrophobic property of the GDL and compromising water removal with respect to operational life. It is arguable that the MPL, which has a comparable material composition to the GDL and is also porous in nature, is susceptible to the same degradation mechanisms. Damage to PTFE coatings can also be induced when GDLs are exposed to subzero operating conditions [94].

\subsection{Ionomer loading in catalyst layer}

The PFSA ionomer loading in the catalyst layer can also have an effect on the transport of reactants to active sites in the catalyst layer. The material is placed in the anode and cathode catalyst layers in order to provide pathways for proton transport $[\mathbf{9 5}, \mathbf{9 6}]$. Water uptake 
in the polymer electrolyte material could cause it to correspondingly expand, thereby reducing the pore sizes in the catalyst layer [97], which can impede reactant supply. The effect is usually reversible since the polymer electrolyte material will also contract when the cell is not in operation, or when liquid water production is less, for example, at lower operating cell current densities. Excessive ionomer loading for a given platinum loading will also inherently impede reactant supply; higher mass transportation losses have been reported due to the impedance to oxygen transportation in the catalyst layer [98]. Ionomer skins can also form on the outer surface of the catalyst layer of the completed membrane electrode assembies (MEA); however, this can be limited to certain methods; for example, the decal/hot-press-transfer method [99]. In general, the fabrication processes for the catalyst layer, such as spraying, painting rolling, and screen printing, all possess a limited degree of precision and ultimately therefore a limited degree of control over the composite structure of the fabricated MEA [100]. Navessin et al. reported that decreasing the ion exchange capacity (IEC) of the ionomer, which is the equivalent to increasing the equivalent weight (EW), results in an increase in hydropobicity, decrease in water content, increase in $\mathrm{O}_{2}$ solubility, and an increase in the ORR current. The EW reflects the ratio of the atomic weight of an element to the valence it assumes in a chemical compound. A low IEC (or high EW) could improve cell performance by facilitating water management.

\subsection{Impedance to transportation due to ice formation}

The effects of subzero operating conditions significantly influence mass transportation losses. The operating temperature of the cell has to be brought up to above freezing before ice formation completely fills the cathode catalyst layer [101]. The instantaneous effect of ice formation is to impede oxygen transport to the catalyst sites and can render entire cells inactive. Freezing conditions are known to weaken the MPL structurally to an extent that renders it prone to material loss from air flow through the GDL [102]. In practice, ice formation can occur in any region of the fuel cell where water resides; it is important, therefore, to remove excess water from the cell prior to start-up and to operate the cell on start-up such that water generated in the cathode catalyst layer is not allowed to freeze. Gas-purging has been identified as a mechanism by which excess water can be removed [103]. In one reported method, gas-purging is done before the cell temperature falls below $0^{\circ} \mathrm{C}$ using dry gases such as nitrogen and oxygen for the anode and cathode respectively, optionally using 30 per cent methanol or 35 per cent ethylene glycol as anti-freeze additives [104]. Another reported method involves purging using gases with limited relative humidities to ensure that the provision of adequate water content in the proton-conducting membrane is not completely compromised [105].

\subsection{Effects of compaction on GDL}

The porous structure and thickness of the GDL also influences two-phase water and reactant transport [106]. Reactant transport can be enhanced when the GDL porosity is in the region of around 0.3-0.6 $[107,108]$, and the removal of liquid water to the gas channel can be enhanced with a linearly graded porosity [107]. The use of thinner GDLs can also improve performance by allowing for greater liquid water mass transfer under steady-state conditions $[107,109]$ and greater reactant mass transfer towards the catalyst layer [108]. The permeability of a GDL can vary according to the carbon type [90]; woven and non-woven GDLs have exhibited slightly higher permeabilities than carbon fibre paper GDLs with similar solid volume fractions [110]. This suggests that, comparatively, the interconnection of void spaces in carbon fibre paper is not as extensive.

A fuel cell stack is held together by compacting together single cells. The corresponding compression can result in a non-uniform pressure distribution across the active area of the cell, which can affect the structural properties of the GDL. Overcompression is argued to be a common occurrence in most fuel cells [111], which causes pores in the GDL to collapse, thereby reducing the porosity, increasing flooding [112], and reducing gas permeability [113]. The deforming over-compression can be less significant under channel regions and occurs mainly between mating surfaces that transmit compaction forces, for example land areas in the BPP and under rib areas where the cell is sealed with gasket material [113-115]. It has been observed that increased compression initially improves the performance of the cell by reducing the interfacial resistance between the BPP and the GDL up to an optimal threshold, whereas further compression thereafter narrows the diffusion path for mass transfer from the gas channels to the catalyst layers [116, 117]. The effects of stress due to over-compression are more pronounced at high current and low pressure [118]. Chang et al. [117] identified the threshold clamping pressure to be in the region of $0.5 \mathrm{MPa}$. The damage to GDLs is manifested through a break-up of fibres and a deterioration of hydrophobic coating, thereby compromising the ability to remove water from the cell [119]. 


\section{OHMIC LOSSES}

\subsection{Resistance to electron transfer in the BPP}

Both resistance to electron transfer and proton transfer contribute towards the overall Ohmic losses incurred in PEFCs. Elements of the cell where electron transfer occurs includes the carbon support in the catalyst layers, the GDL and the BPP. Proton transfer occurs in the polymer electrolyte matrix dispersed in the catalyst layers and the polymer electrolyte between the anode and cathode catalyst layers.

Although the BPP provides the bulk of the mechanical strength of the stack, it also serves as a current collector, as a thermally conductive medium to remove excess heat energy from single cells, and as a device to supply reactants and to remove water via flow fields on both faces of the plate. However, they must withstand the acidic and humid conditions within the stack. Corrosion is a significant issue for BPPs, which can lead to the loss of electrical conductivity. While the BPP must have high mechanical strength, low susceptibility to material dissolution, low susceptibility to the release of metal ions, and high corrosion resistance, the bulk electrical conductivity must be high and the interfacial contact resistance (ICR) must be kept low [120]. As an indication, targets set for mechanical strength and electrical conductivity are $44.26 \mathrm{MPa}$ and $100 \mathrm{~S} / \mathrm{cm}$, respectively [121]. These attributes have to be achieved with materials and processes that are compatible with low cost and high volume manufacturability concepts. As such, an array of different chemical compositions and synthesizing processes have been investigated to identify how these requirements can be simultaneously met.

\subsubsection{Graphitic BPP}

Graphite is conventionally regarded as the standard material for BPPs because of its high conductivity $(300 \mathrm{~S} / \mathrm{cm})[\mathbf{1 2 1}]$ and high corrosion resistance [122]. However, graphite BPPs are susceptible to fracturing due to shock and mechanical vibration, are permeable to gases and can be costly to machine in high volumes [120].

\subsubsection{Stainless steel BPPs}

While corrosion-resistant metals have better mechanical properties and are cheaper to machine in high volumes than graphite plates, the chemical process that provides corrosion resistance can also compromise its electrical conductivity. Stainless steel (SS) develops a $\mathrm{Cr}_{2} \mathrm{O}_{3}$ passivating layer on the surface, which prevents the bulk metal from corrosion. This thin film however impedes electron transfer and therefore raises the ICR. The consequent ohmic heating thereby compromises the electrical energy that can be harnessed from single cells. The bulk resistivity is however insignificant in relation to the surface resistance due to this film [123].

SS is the standard alloy for metallic BPPs and its major constituents are $\mathrm{Fe}, \mathrm{Cr}$, and $\mathrm{Ni}$. There are mainly six relevant grades of SS for BPPs, distinguishable by their chemical compositions: SS316L (16.20-16.80 per cent Cr, 10.10-10.30 per cent Ni); SS317L (18.10-18.60 per cent Cr, 12.45-12.75 per cent Ni); SS904L (20.48 per cent $\mathrm{Cr}, 24.59$ per cent $\mathrm{Ni}$ ); SS349 ${ }^{\mathrm{TM}}$ (23 per cent $\mathrm{Cr}$, 14.5 per cent Ni); [124] SS310 (25 per cent $\mathrm{Cr}, 20$ per cent $\mathrm{Ni}$ ) [123]; and AISI446 (28.367 per cent Cr, 2.958 per cent Ni) [125]. The conductivity of SS316 is, for example, $\sim 51 \mathrm{~S} / \mathrm{cm}[\mathbf{1 2 1}]$. It has been shown that those grades of SS with a higher content of $\mathrm{Cr}$ and Ni, SS904L for example, result in the formation of thinner passive oxide films with low ICR. Raising Cr content alone, however, can improve corrosion resistance and it is possible to attain a low ICR if a clean, stable, and integral surface is developed [123-127]. The effect of Cr content on corrosion resistance is also evident in amorphous Fe-based alloys such as $\mathrm{Fe}_{50} \mathrm{Cr}_{18} \mathrm{Mo}_{8} \mathrm{Al}_{2} \mathrm{Y}_{2} \mathrm{C}_{14} \mathrm{~B}_{6}[\mathbf{1 2 8}]$. Amorphous alloys intrinsically possess high corrosion resistance and high strength $(\sim 2 \mathrm{GPa})$ due to the absence of defects such as grain boundaries and dislocations [128]. In addition, surface treatment of $\mathrm{SS}$ in the form of a selective dissolution process can improve the metallurgical surface structure, ensuring that it is defect-free, solid, and integral [126]. Smoother surfaces can result in reduced interfacial contact resistances.

\subsubsection{Coating of SS substrate}

Corrosion resistance can be improved if SS is coated as a substrate. When coated with TiN, if coating defects such as micro-cracks and pinholes can be minimized, a higher corrosion resistance and electrical conductivity for SS316 can be achieved [129]. SS can also be coated with conducting polymers such as polypyrrole and polyaniline [130-132]. The interfacial contact resistance however is five times that of graphite at a compaction force of $200 \mathrm{~N} / \mathrm{cm}^{2}$, and reduced to one to two times that of graphite at $400 \mathrm{~N} / \mathrm{cm}^{2}[\mathbf{1 3 0}]$. The number of deposition cycles that the substrate is subjected to during the electropolymerization process dictates the thickness of the polymer film; the coating is known to degenerate with time, and coating compositions need to be modified in order to maintain the protective properties of the polymer surface [132]. SS304 coated with nitride layers using the physical vapour deposition (PVD) method has also been reported, which results in interfacial contact resistances less than that of uncoated SS904L [133]. Coating does generally however add to the cost of the final product [121]. 
Other forms of metallic BPP include copper alloys such as C-17200 copper-beryllium, which form electrically conductive oxides [134] and Ni-based alloys with lower amounts of $[\mathrm{Fe}+\mathrm{Cr}]$, resulting in oxides with reduced ICR [133].

\subsubsection{Moulded BPP}

Injection and compression moulding as low-cost, high-volume manufacturing processes could arguably mitigate the high production costs associated with machined graphite and SS BPPs. The process requires the synthesis of a mouldable compound. In general, polymer-based compounds can be susceptible to shrinkage after the moulding process and could warp with time. Also, inhomogeneous pre-mixing of the carbon-polymer compounds can give rise to the formation of polymer-rich boundaries in the mould, compromising the electrical conductivity closer to the surface. However, the literature suggests that these are not necessarily limiting factors. Two reported compounds include carbon-polymer [135], for example graphite powder (80-60 wt.\%) with vinyl ester (20-40 wt.\%) [136], and Nylon-6 with SS316L alloy fibres [137]. The bulk conductivities of the resulting materials are $5-150$ and $60 \mathrm{~S} / \mathrm{cm}$ for the carbonpolymer [135] and Nylon-6-SS316L compounds, respectively. Commercially available carbon-based BPPs and BPP materials include those based on phenolic resin and other polymers such as polyvinylidene difluoride (PVDF) and polypropylene [138-141]. The conductivity of these materials range from $\sim 30$ to $200 \mathrm{~S} / \mathrm{cm}$ with flexural strength in the region of 40-50 MPa. Other compounds constituted of vinyl ester resin and graphite powder with organoclay have been reported with bulk conductivities in the region of $260-312 \mathrm{~S} / \mathrm{cm} \mathrm{[142]}$. The organoclay is prepared by ionic exchange of montmorillonite (MMT) with poly(oxypropylene)-backboned diamine intercalating agents. Higher MMT content improves flexural strength, impact strength, and anticorrosive protection, but slightly reduces the electrical conductivity.

\subsection{Resistance to proton transfer in the polymer electrolyte membrane}

\subsubsection{Impurity ions}

Resistance to proton transfer in the polymer electrolyte material is characterized by the interplay between absorbed water, cations and fixed charge ionic clusters of the membrane electrolyte. Cations in the form of foreign impurity ions can displace protons and enter the electrolyte membrane, decreasing the proton conductivity in proportion to the ionic charge of the cation [20]. Foreign ions reported in the literature include the alkali metals $\mathrm{Li}^{+}, \mathrm{Na}^{+}, \mathrm{K}^{+}, \mathrm{Rb}^{+}$, and
$\mathrm{Cs}^{+}$[143-149]; the alkaline earths $\mathrm{Mg}^{2+}, \mathrm{Ca}^{2+}, \mathrm{Sr}^{2+}$, and $\mathrm{Ba}^{2+}[\mathbf{1 5 0}-152]$; the transition elements $\mathrm{Ag}^{+}, \mathrm{Ni}^{2+}$, $\mathrm{Mn}^{2+}, \mathrm{Cu}^{2+}, \mathrm{Zn}^{2+}, \mathrm{Cr}^{3+}$, and $\mathrm{Fe}^{3+}[\mathbf{1 5 2 - 1 5 5}]$; rare earths $\mathrm{La}^{3+}[\mathbf{1 5 2}]$ and $\mathrm{Al}^{3+}[\mathbf{1 5 5}]$; and ammonium derivatives $\mathrm{R}_{n} \mathrm{NH}_{4-n}^{+}$(where $\mathrm{R}=\mathrm{H}, \mathrm{CH}_{3}, \mathrm{C}_{2} \mathrm{H}_{5}, \mathrm{C}_{3} \mathrm{H}_{7}, \mathrm{C}_{4} \mathrm{H}_{9}$ and $n=1$ to 4$)[156,157]$. Sources of impurity ions include impure gas feeds, corroded materials in the fuel cell stack or reactant supply system, i.e. transition metal ion contaminants such as $\mathrm{Cu}^{2+}, \mathrm{Ni}^{2+}$, and $\mathrm{Fe}^{3+}[\mathbf{1 5 3}]$, fittings, tubing, or indeed ions in the water or coolant supply [149].

As discussed, compromising the hydrated state of the membrane results in the loss of proton conductivity. Water transport through the cell governs how well the membrane is hydrated, and water transport itself is characterized by its diffusivity and its transfer coefficient. For the general case of operation under uncontaminated conditions, the water content of the membrane decreases non-linearly through the membrane thickness towards the anode, thereby resulting in a decrease in proton conductivity. In addition, the gradient in water content across the membrane will increase with current density. This reflects the rise in electro-osmotic drag with increasing current density, resulting in a comparably large amount of water being taking away from the anode to the cathode in relation to that diffusing through the PFSA-based membrane from the cathode to the anode [27]. Membrane contamination can increase the non-uniformity in water content and decrease the overall water content profile. The literature reports that the penetration of impurity ions into the membrane induces [20]: (a) a decrease in the diffusion coefficient of water, and (b) an increase in the water-transfer coefficient.

Water can reside in the membrane in the form of one of three possible population groups [145]: (a) Henry or Flory-Huggins-type populations where water molecules are sorbed by an ordinary dissolution mechanism; (b) Langmuir-type populations where water molecules reside in a hydration layer around cations and sulphonic charge groups due to the strong interactions caused by hydrogen bonds; and (c) water cluster populations. Water clusters can be distinguished from Langmuir-type populations and are known to become dominant populations when the water activity in the membrane is greater than around 0.6. Clustering can change depending upon the type of cation penetrating the membrane; it is known to increase in the order of $\mathrm{Cs}^{+}>\mathrm{Li}^{+}>\mathrm{H}^{+}$. Legras et al. reported that the water clusters compromise the mobility of water overall, which correspondingly results in a decrease in water diffusivity. Shi and Anson [152] reported that the replacement of protons by impurity ions can induce electro-static cross-linking of ionic domains or the formation of sulphonate salts, causing the membrane to contract and expel water. This can also result in the loss of 
water diffusivity [20]. Kundu et al. [149] reported that physical cross-linking of ionic domains alters the mechanical properties of the membrane, causing an increase in membrane stiffness. Young's modulus is shown to increase by one order of magnitude with increasing ionic radius, in the order $\mathrm{Ni}^{2+}>\mathrm{Cu}^{2+}>$ $\mathrm{Na}^{+}>\mathrm{K}^{+}$.

Water transfer coefficients reflect the combined contributions of: (a) electro-osmotic drag, where an ion transports peripherally bound water molecules, and (b) hydrodynamic pumping where water molecules are pumped by an ion during the ion transport process [157]. The transport of protons through the polymer electrolyte from the anode to the cathode is known to induce the aforementioned electro-osmotic drag flux [158]. For other ions, the magnitude of each contributory transport mode depends upon the existence of hydrophilic and hydrophobic parts of the ion. Through the investigation of ammonium derivatives, Xie and Okada [157] reported that such ions with hydrophobic skeletons tended not to have peripherally-bound water molecules and instead tended to contribute to the transfer coefficient simply through hydrodynamic pumping [157]. Other cations, including fully hydrophilic cations, with a high charge density and a high enthalpy of hydration tended to carry more water molecules during transport and that the electroosmotic drag increases with increased water content $[150,157,159]$. Overall this illustrates that while the transfer of protons across the polymer electrolyte material induces an electro-osmotic drag, overall water transfer can indeed be unfavourably magnified as water interacts with impurity ions. The duration over which the degradation is prolonged depends upon the concentration of the impurity ions [146] and the length of time that the impurity ions reside within the polymer electrolyte membrane. Impurities with large diameters can penetrate the membrane and induce a plugging effect, compromising hydration and thus proton conductivity [157]. In some instances, proton-induced water transfer due to electro-osmotic drag is necessary for counterflow configurations, as discussed previously. However in general, water transport due to the presence of impurity ions can indeed hasten membrane dehydration and in addition, the adverse effect on membrane performance is exacerbated when the impurity ions are concentrated closer to the anode and cathode catalyst layers $[160,161]$.

\subsubsection{Anisotropic expansion}

The swelling phenomenon experienced in fuel cells that use PFSA-based materials due to the uptake of water can lead to anisotropic expansion. Casciola et al. [162] reported that through-plane conductivity could decay when such swelling occurs, precipitated by high operating temperatures $\left(120^{\circ} \mathrm{C}\right)$ and high relative humidity ( $>90$ per cent).

Membrane expansion could be restrained by cell compaction. However, it has already been argued that the stresses actually experienced in operating fuel cells are likely to be less than those required to sufficiently constrain the membrane [163]. Reinforcing the membrane structurally, however, provides a more robust method. Methods include dispersing PTFE fibrils within membranes (fibril content of $2.7 \mathrm{wt} . \%$ ) [164], dispersing carbon nanotubes within Nafion membranes (CNT content of 1 wt.\%) [165] and the use of porous, expanded PTFE sheets that are bonded with membrane resins on both sides [166-168]. A $50 \mu \mathrm{m}$ thick membrane made of recast Nafion has a tensile strength of $22.08 \mathrm{MPa}$. Dispersing 1 wt.\% CNT within the membrane will increase this by 68.8 per cent $[\mathbf{1 6 5}]$. The use of a PTFE porous sheet for reinforcement increases the tensile strength by 87.5 per cent [165]. The dimensional change for recast Nafion in water at $80^{\circ} \mathrm{C}$ is 25 per cent [167]. For Nafion reinforced with dispersed CNT the dimensional change can decrease to 12.4 per cent [165] and for PTFE-reinforced Nafion this can decrease to 10 per cent [167]. At 90 per cent $\mathrm{RH}$, expanded PTFE reinforcement can suppress inplane dimensional change from 12 per cent down to 2.5 per cent [169].

\section{EFFICIENCY LOSSES AND CATASTROPHIC CELL FAILURE}

Loss of efficiency and catastrophic cell failure can be induced when the strength and stability of the fuel cell materials are degraded irreversibly by mechanical or chemical attack. Rigid elements such as the BPP are susceptible to cracking under mechanical stress and vibration. Seals are susceptible to oxidation [170], which compromises its functionality and can eventually result in rupture.

The electrolyte material has to survive under cyclic loads and through chemically induced structural degradation while serving its primary role as a proton conductor. Efficiency losses in the electrolyte membrane can result as an inherent consequence of employing thin membranes $[\mathbf{1 7 1}, \mathbf{1 7 2}]$ or by in-situ membrane thinning, allowing hydrogen to diffuse through the electrolyte from anode to cathode. Membrane thinning largely reflects a loss of chemical structure, primarily induced by peroxide radical attack. Pinhole formation is a notable precursor to catastrophic cell failure, propagating from localized regions where temperature extremes exist which mechanically degrade the fuel cell materials. This includes regions exposed to thermal hot-spots or ice formation. The purpose of this section is to discuss 
the irreversible degradation mechanisms caused by mechanical and chemical attack.

\subsection{Mechanical attack}

The impedance to transport in the porous layers of the cell due to ice formation was discussed previously. It has also been reported that ice formation caused as a consequence of operation at subzero conditions down to $-20^{\circ} \mathrm{C}$ can cause the catalyst layer to delaminate from both the membrane and the GDL [94]. The surface of the electrolyte membrane has also been observed to become rough at subzero conditions, leading to the formation of cracks and eventual pinholes [94].

The formation of thermal hot-spots has also been reported in the literature, as instigated through different mechanisms $[\mathbf{1 7 3}, 174]$. Hottinen et al. [174] reported that a significant portion of the heat generated under the channel sections of the BPP has to flow in the in-plane direction. This induces a lateral temperature gradient within the electrode, resulting in the possible formation of hot spots below the channel. The beginning of rib areas where current enters the GDL from the BPP could also be regions of high ohmic heating, giving rise to other hotspots. The effect of uneven temperature distributions can be magnified when superimposed with inhomogeneous compression. Stanic et al. [173] reported evidence of the formation of pinholes in regions where carbon fibres at the MEA-GDL interface created spots of high compression, accelerating membrane creep. High reaction rates in the vicinity of highly compressed membrane regions can raise the generation of heat energy, which also raises the local temperature. Overall, the local strength of the membrane at these higher-temperature, highcompression hotspots can reduce and so cause the electrolyte membrane to collapse. Membrane durability is also affected by repeated swelling and contraction induced by variations in relative humidity (RH) [175]. Kusolgu et al. [176] investigated inplane stresses caused by in-plane membrane swelling and found that swelling as a phenomenon can have a more dominant impact on fatigue stresses than campling conditions or the membrane thickness. Thermal hotspots can also develop in regions where hydrogen and oxygen combine exothermically on Pt catalyst sites, causing a cycle of increasing crossover and continual propagation of pinholes [177]. In general, hydro-thermal stressing can significantly affect the durability of PFSA-based membranes $[169,178-180]$. However, dimensional change due to hydro-thermal stressing can be restrained by reinforcing PFSA membranes with expandable PTFE, as discussed [169].
It is possible that irregularities in the electrolyte membrane or MEA could be induced during manufacture. Ensuring the absence of contaminants and uniformity in the thickness of membrane batches depends upon quality control during the manufacturing process. Curtin et al. [181] reported DuPont's manufacturing techniques for PFSA membranes, which includes two inspection points for membrane film thickness and one inspection point for defects.

In general, greater control over manufacturing quality could be granted by adopting manufacturing processes and quality control practices that have become highly developed in similar industries. This applies all the way through the supply-chain from PEFC subcomponent level through stack subsystem level to application system level. Relevant examples include the recoding media, semiconductor, battery, and PV industries [182] and well-established standards for manufacturing and testing [183-185].

\subsection{Chemical attack}

Chemical attack in PFSA-based membranes can occur due to the presence of defects in the polymer group. The defects exist as groups in the polymer that can interact with active radicals, resulting in the chemical degeneration of the PFSA-based material.

The PFSA polymer is synthesized from a copolymer of tetraflouroethylene (TFE) and perfluoro(4-methyl3,6-dioxa-7-octene-1-sulfonyl fluoride) by chemically converting the pendant $\mathrm{SO}_{2} \mathrm{~F}$ sulphonyl fluoride groups to sulphonic acid $\mathrm{SO}_{3} \mathrm{H}[\mathbf{1 8 1}, \mathbf{1 8 6}]$. The $\mathrm{SO}_{3} \mathrm{H}$ is ionically bonded such that the end of the side chain contains an $\mathrm{SO}_{3}^{-}$and an $\mathrm{H}^{+}$ion $[\mathbf{1 0}]$.

\subsubsection{Formation of defective end groups}

End group defects can be generated during polymer synthesis as a consequence of chemical or mechanical processes; initiators, transfer agents, solvents, or contaminants could induce defects during chemical processing, while ageing, heating, or extrusion could also induce defects during the handling of the polymer [187]. Pianca et al. [187] identified the following end groups: carboxylic acid $\left(-\mathrm{CF}_{2}-\mathrm{COOH}\right)$, amide $\left(-\mathrm{CF}_{2}-\right.$ $\left.\mathrm{CONH}_{2}\right)$, perfluorovinyl $\left(-\mathrm{CF}_{2}-\mathrm{CF}=\mathrm{CF}_{2}\right)$, acyl fluoride $\left(-\mathrm{CF}_{2}-\mathrm{COF}\right)$, difluoromethyl $\left(-\mathrm{CF}_{2}-\mathrm{CF}_{2} \mathrm{H}\right)$, and ethyl $\left(-\mathrm{CF}_{2}-\mathrm{CH}_{2}-\mathrm{CH}_{3}\right)$. Alentiev et al. [188] identified other end groups including $-\mathrm{CF}_{2}-\mathrm{CF}=\mathrm{O}$ and $-\mathrm{CF}_{2}-\mathrm{CF}=\mathrm{O}$ and residual $\mathrm{C}-\mathrm{H}$ bonds in the main chain such as $\mathrm{R}_{f}-$ $\mathrm{CFH}-\mathrm{R}_{f}^{\prime}$. It is primarily the H-containing end groups that are of particular interest for PFSA membranes in fuel cell environments, which can undergo aggressive chemical attack in the presence of peroxide radicals at low relative humidity conditions and temperatures in excess of $90^{\circ} \mathrm{C}[\mathbf{1 8 1}]$. 


\subsubsection{Formation of hydrogen peroxide}

Hydrogen peroxide can be formed through three reported processes. The first occurs as a consequence of oxygen reduction at the cathode [189]

$$
\mathrm{O}_{2}+2 \mathrm{H}^{+}+2 \mathrm{e}^{-} \longrightarrow \mathrm{H}_{2} \mathrm{O}_{2}
$$

The second occurs as a consequence of oxygen crossover from the cathode to the anode, or when air bleeds to the anode side [189-191]

$$
\begin{aligned}
& \mathrm{Pt}+1 / 2 \mathrm{H}_{2} \longrightarrow \mathrm{PtH} \\
& 2 \mathrm{H}^{*}+\mathrm{O}_{2} \longrightarrow \mathrm{H}_{2} \mathrm{O}_{2}
\end{aligned}
$$

La Conti et al. [192] identified the intermediate formation of hydroperoxy $\left(\mathrm{HO}_{2}^{\bullet}\right)$

$$
\begin{aligned}
& \mathrm{H}_{2} \longrightarrow 2 \mathrm{H}^{\bullet} \text { (on Pt or Pt-alloy catalyst) } \\
& \mathrm{H}^{\bullet}+\mathrm{O}_{2} \longrightarrow \mathrm{HO}_{2}^{\bullet} \\
& \mathrm{HO}_{2}^{\bullet}+\mathrm{H}^{+} \longrightarrow \mathrm{H}_{2} \mathrm{O}_{2}
\end{aligned}
$$

The third occurs due to the converse crossover of hydrogen from the anode to the cathode, making it possible for hydrogen peroxide to form in the cathode catalyst layer $[\mathbf{1 9 3}, \mathbf{1 9 4}]$. It has been reported that hydrogen peroxide formation can be hastened by the presence of chloride ions, which act as site-blocking species, reducing the number of active sites for the ORR, and reducing the number of pairs of Pt sites required to break the $\mathrm{O}-\mathrm{O}$ bond [195]. Chloride anions can originate from the fuel cell catalyst synthesizing process and can be present as a water contaminant in humidified reactant supplies.

\subsubsection{Formation of peroxide radicals}

Highly oxidative peroxide radicals can subsequently form from the decomposition of hydrogen peroxide and as active species can decompose PFSA-based membranes [186]. Impurity ions such as the transition metals $\mathrm{Cu}^{2+}$ and $\mathrm{Fe}^{2+}$ are known to be catalysts for the decomposition of hydrogen peroxide [186] and can originate from piping tubes and tanks of fuel cell systems. The Haber-Weiss mechanism details the formation of reactive oxygen hydroxyl $\left(\mathrm{HO}^{\bullet}\right)$ and hydroperoxyl radicals for $\mathrm{Fe}^{2+}[\mathbf{1 8 6}]$

$$
\begin{aligned}
& \mathrm{H}_{2} \mathrm{O}_{2}+\mathrm{Fe}^{2+} \longrightarrow \mathrm{HO}^{\bullet}+\mathrm{OH}^{-}+\mathrm{Fe}^{3+} \\
& \mathrm{Fe}^{2+}+\mathrm{HO}^{\bullet} \longrightarrow \mathrm{Fe}^{3+}+\mathrm{OH}^{-} \\
& \mathrm{H}_{2} \mathrm{O}_{2}+\mathrm{HO}^{\bullet} \longrightarrow \mathrm{HO}_{2}^{\bullet}+\mathrm{H}_{2} \mathrm{O}
\end{aligned}
$$

$$
\begin{aligned}
& \mathrm{Fe}^{2+}+\mathrm{HO}_{2}^{\bullet} \longrightarrow \mathrm{Fe}^{3+}+\mathrm{HO}_{2}^{-} \\
& \mathrm{Fe}^{3+}+\mathrm{HO}_{2}^{\bullet} \longrightarrow \mathrm{Fe}^{2+}+\mathrm{H}^{+}+\mathrm{O}_{2}
\end{aligned}
$$

It is steps (8) and (10) that result in the formation of hydroxyl and hydroperoxyl radicals, respectively. For bivalent transition metals in general $\left(M^{2+}\right)$, radical formation can be generalized by the following mechanism [192]

$$
\begin{aligned}
& \mathrm{H}_{2} \mathrm{O}_{2}+\mathrm{M}^{2+} \longrightarrow \mathrm{HO}^{\bullet}+\mathrm{OH}^{-}+\mathrm{M}^{3+} \\
& \mathrm{H}_{2} \mathrm{O}_{2}+\mathrm{HO}^{\bullet} \longrightarrow \mathrm{HO}_{2}^{\bullet}+\mathrm{H}_{2} \mathrm{O}
\end{aligned}
$$

\subsubsection{Mechanism of peroxide attack on defective end groups}

Peroxide radicals in the presence of defective polymer end groups proceed to decompose the polymer structure. Curtin et al. [181] detail the following threestep mechanism whereby hydroxyl radicals attack carboxylic acid end groups:

Step 1:Abstraction of hydrogen from an acid end group

$$
R_{\mathrm{f}}-\mathrm{CF}_{2}-\mathrm{COOH}+\mathrm{HO}^{\bullet} \longrightarrow R_{\mathrm{f}}-\mathrm{CF}_{2}^{\bullet}+\mathrm{CO}_{2}+\mathrm{H}_{2} \mathrm{O}
$$

Step 2: Reaction of perfluorocarbon radical with hydroxyl radical

$$
R_{\mathrm{f}}-\mathrm{CF}_{2}^{\bullet}+\mathrm{HO}^{\bullet} \longrightarrow R_{\mathrm{f}}-\mathrm{CF}_{2} \mathrm{OH} \longrightarrow R_{\mathrm{f}}-\mathrm{COF}+\mathrm{HF}
$$

Step 3: Hydrolysis of acid fluoride

$$
R_{\mathrm{f}}-\mathrm{COF}+\mathrm{H}_{2} \mathrm{O} \longrightarrow R_{\mathrm{f}}-\mathrm{COOH}+\mathrm{HF}
$$

The release of fluoride therefore reflects the decomposition of the PFSA membrane. Fluoride emission rates (FER) can be determined by sampling the fluoride content of water in the anode and cathode exhaust [196]. Assuming a zero-order reaction for the production of fluoride ions, it is possible to postulate the following relationship to determine the rate at which Nafion is decomposed [197]

$$
r_{\mathrm{d}}=\frac{\Delta M_{\overline{\mathrm{F}}}}{M_{\mathrm{F}-\text { Nafion }} \Delta t}
$$

where $\Delta M_{\overline{\mathrm{F}}}$ is the change in the amount of $\mathrm{F}^{-}$released in $\mu \mathrm{mol}, M_{\mathrm{F}-\mathrm{Nafion}}$ is the total amount of $\mathrm{F}$ in the Nafion, and $\Delta t$ is the timestep in hours. The literature demonstrates that the FER technique is being increasingly applied to determine ionomer degradation [190, 196-198]. 


\subsubsection{Effect of membrane degradation due to peroxide attack}

The effect of peroxide attack is to alter the membrane structure and the chemical properties of the PFSA membrane. Loss of sulphonic end groups results in the loss of electrical conductivity, thereby increasing the ohmic resistance. Continual membrane degradation due to peroxide radical attack and subsequent fluoride release results in membrane thinning. This increases the diffusion of oxygen and hydrogen in opposing directions from the cathode and anode, respectively. Primarily, it is the crossover of hydrogen that increases because of the high effective diffusivity of hydrogen molecules [13].

\section{SUMMARY}

The performance degradation, failure modes, and the associated causes discussed in chapters 3 to 6 are summarized in Tables 1 and 2. Faults are listed

Table 1 Summary of PEFC degradation and failure modes and their causes: activation and mass transportation losses

\begin{tabular}{llll}
\hline $\begin{array}{l}\text { Degradation/ } \\
\text { failure mode }\end{array}$ & $\begin{array}{l}\text { Fuel cell } \\
\text { component }\end{array}$ & Fault & Cause \\
\hline
\end{tabular}

Increase of activation Platinum catalyst losses

Increase of mass transportation losses catalyst layer

Porous and void
(1) Platinum agglomeration causing loss of EASA

(2) Platinum migration causing loss of catalyst material

(3) Adsorption of atmospheric contaminants on platinum causing loss of EASA

(4) Adsorption of fuel impurities on platinum causing loss of EASA

(5) Loss of catalyst due to chemical attack and formation of silicone/oxygen/platinum particles

Geometric structure of the catalyst layer

Carbon support in regions of the cell; catalyst layers, GDLs, BPP flow fields

freezing and melting water, resulting current drawn
Geometric structure of catalyst layer

(10) Impedance to transport attributable to presence of ionomer

(11) Impedance to transport attributable to ice formation

GDL

(12) Loss of porosity, increased flooding in increased pore size and reduced EASA

(7) Corrosion of carbon to support the current above that provided by the fuel when the cell is supplied with insufficient fuel to support the

(8) Flooding caused by the accumulation and condensation of water vapour to induce two-phase flow

(9) Loss of hydrophobicity in porous regions of the cell treated with hydrophobic material and reduced gas permeability
(1) Repetitive on/off load cycling

(2) High voltage induce at cathode equivalent to OCV due to residual hydrogen

(3) Loss of carbon support

(4) Solubility of platinum when cell is operated through hydrogen-air open circuit to air-air open circuit

(5) Air impurities such as $\mathrm{NO}_{2}, \mathrm{SO}_{2}$, and $\mathrm{H}_{2} \mathrm{~S}$

(6) Fuel impurities such as $\mathrm{CO}$ and reduction of $\mathrm{CO}_{2}$ to $\mathrm{CO}$

(7) Chemical degradation of silicone sealant

(8) Residual water in catalyst layers

(9) Fuel starvation

(10) Partial coverage of hydrogen on catalyst sites

(11) Localized flooding

(12) Low flowrate of channel gases

(13) Low pressure in gas flow channels

(14) Flow-field geometry or configuration

(15) Degradation of polymer electrolyte in catalyst layer due to impurity ions

(16) Loss of material/material properties due to repeated thermal cycling/high operating temperature

(17) Delamination caused by repeated thermal cycling

(18) Damage to material caused by exposure to subzero conditions

(19) Cell over-compression, impacting the GDL

(20) Ionomer expansion on water uptake causing pores to collapse

(21) Excessive ionomer loading

(22) Formation of ionomer skins on catalyst layers

(23) Lack of control during MEA processing

(24) Presence of residual water from previous shut-down

(25) Operation at subzero temperatures

(26) Overcompression and inhomogeneous compression transmitted by BPPs, induced during stack assembly or during operation 
Table 2 Summary of PEFC degradation and failure modes and their causes: ohmic losses, efficiency losses, and catastrophic cell failure

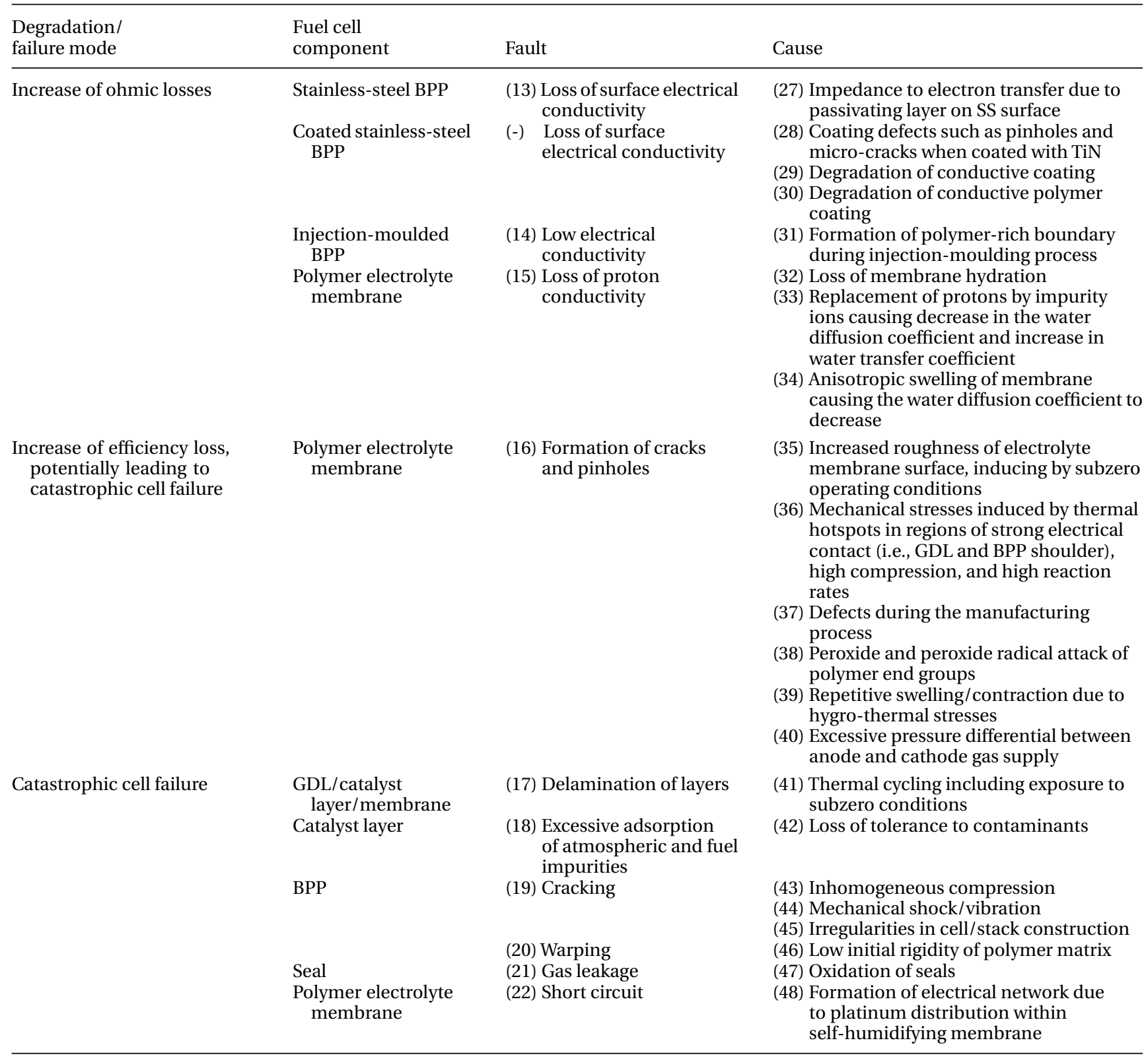

according to the physical component of the PEFC assembly where they originate or reside.

\section{CONCLUSIONS}

The current review provides a structured understanding of the phenomenological processes that occur within hydrogen-fuelled PEFCs, which induce performance degradation and failure. The review considers both standard and non-standard methods in fuel cell design, manufacture and operation. The conclusions of the current review are as follows:
1. PEFC reliability is defined in terms of both performance degradation and cell failure.

2. Performance degradation or failure can occur as a consequence of gradual processes, where certain operating conditions or operating routines cause a systematic degradation of structural and electrokinetic properties of PEFC components. Latent flaws in component design and manufacture can also lead to performance degradation or failure.

3. The identified phenomenological processes that lead to performance degradation are organized in terms of potentially irreversible increases in activation losses, mass transportation losses, ohmic losses, and efficiency losses. 
4. Cell failure can occur if the loss mechanisms listed above cause an irreversible drop of overall cell performance below a critical threshold; the exact threshold depends upon the requirements of the target application.

5. The performance degradation and failure modes identified through the literature pertain to the following PEFC components:

(a) PFSA-based membrane

(b) Catalyst layer

(i) Carbon support

(ii) PFSA-based ionomer matrix

(iii) Catalyst particles

(iiii) Porous structure of the catalyst layer

(c) Gas diffusion media

(i) Hydrophobic treatment material in the GDL

(ii) Porous structure of the GDL

(d) BPP
(i) SS BPPs
(ii) Molded BPPs

(e) Sealing material

(i) Silicone-based seals

6. In reviewing the performance degradation and failure modes, 22 common faults can be identified.

7. The identified 22 common faults in hydrogenfuelled PEFCs are induced by 48 general causes.

The review also discusses newer aspects of fuel cell design, manufacture and operation as remedial measures that limit performance degradation and failure. In terms of MEA development, there is emphasis on high mechanical strength, dimensional stability, and water management for proton conductivity. For BPP and GDL development, there is emphasis on improving the homogeneity of flows through channels and porous media and on establishing materials, material preparation, material treatment, and fabrication processes for high mechanical strength, high electrical conductivity, and low susceptibility to chemical attack. Manufacturing and quality control is a critical area and is continually developing as the technology progressively matures. The emphasis here is on adopting scalable manufacturing processes and practices from similar established industries, establishing repeatable precision processes, and on adopting quality control practices.

In conclusion, the review highlights that for practically all aspects of fuel cell development the factors that impact performance degradation and failure are well defined. The review also demonstrates that there is a drive to better understand the fundamental mechanisms behind performance degradation and failure and to translate this into technological advancements in order to advance technology readiness.

\section{REFERENCES}

1 Mehta, V. and Cooper, J. S. Review and analysis of PEM fuel cell design and manufacturing. J. Power Sources, 2003, 114, 32-53.

2 Haile, S. M. Fuel cell materials and components. Acta Mater., 2003, 51, 5981-6000.

3 Cooper, J. S. Design analysis of PEMFC bipolar plates considering stack manufacturing and environmental impact. J. Power Sources, 2004, 129, 152-169.

4 Yu, P. T., Gu, W., Makharia, R., Wagner, F. T., and Gasteiger, A. The impact of carbon stability on PEM fuel cell startup and shutdown voltage degradation. Durability - fuel starvation and start/stop degradation. In the 210th ECS Meeting, Cancun, Mexico, 29 October-3 November 2006.

5 Fietelberg, A. S., Stathopoulos, J., Qi, Z., Smith, C., and Elter, J. F. Reliability of plug power GenSys ${ }^{\mathrm{TM}}$ fuel cell systems. J. Power Sources, 2005, 147, 203-207.

6 DoD. Technology readiness assessment (TRA) deskbook, 2005, available from www.dod.mil/ddre/doc/ tra_deskbook.pdf, accessed 23 May 2008.

7 Andrews, J. D. and Moss, T. R. Reliability and risk assessment, 2nd edition, 2002 (PEP Ltd., London).

8 MIL-STD-1629A. Procedures for performing a failure modes and criticality analysis, 1998, available from www.weibull.com/knowledge/milhdbk.htm.

9 Samms, S. R., Wasmus, S., and Savinell, R. F. Thermal stability of Nafion in simulated fuel cell environments. J. Electrochem. Soc., 1996, 143(5), 1498-1504.

10 Larminie, J. and Dicks, A. Fuel cell systems explained, 2nd edition, 2003 (John Wiley \& Sons, Chichester).

11 Commer, P., Harting, C., Seeliger, D., and Sphor, E. Modeling of proton transfer in polymer electrolyte membranes on different time and length scales. Mol. Simul., 2004, 30, 755-763.

12 Pei, H., Hong, L., and Lee, J. Y. Polymer electrolyte membrane based on 2-acrylamido-2-methyl propanesulfonic acid fabricated by embedded polymerization. J. Power Sources, 2006, 161, 949-956.

13 Xie, J., Wood, D. L., III, Wayne, D. M., Zawodzinski, T. A., Atanassov, P., and Borup, R. L. Durability of PEFCs at high humidity conditions. J. Electrochem. Soc., 2005, 152(1), A104-A113.

14 Xie, J., Wood, D. L., III, More, K. L., Atanassov, P., and Borup, R. L. Mictrostructural changes of membrane electrode assemblies during PEFC durability testing at high humidity conditions. J. Electrochem. Soc., 2005, 152(5), A1011-A1020.

15 Lee, S.-Y., Cho, E., Lee, J.-H., Kim, H.-J., Lim, T.-H., Oh, I.-H., and Won, J. Effects of purging on the degradation of PEMFCs operating with repetitive on/off cycles. J. Electrochem. Soc., 2007, 154(2), B194-B200.

16 Zhai, Y., Zhang, H., Liu, G., Hu, J., and Yi, B. Degradation study on MEA in $\mathrm{H}_{3} \mathrm{PO}_{4} / \mathrm{PBI}$ high-temperature PEMFC life test. J. Electrochem. Soc., 2007, 154(1), B72-B76.

17 Darling, R. M. and Meyers, J. P. Mathematical model of platinum movement in PEM fuel cells. J. Electrochem. Soc., 2005, 152(1), A242-A247.

18 Aragane, J., Murahashi, T., and Okada, T. Change of Pt distribution in the active components of phosphoric 
acid fuel cell. J. Electrochem. Soc., 1988, 135(4), 844-850.

19 Cho, E. A., Ko, J.-J., Ha, H. Y., Hong, S.-A., Lee, K.-Y., Lim, T.-W., and Oh, I.-H. Characteristics of the PEMFC repetitively brought to temperatures below $0{ }^{\circ} \mathrm{C}$. J. Electrochem. Soc., 2003, 150(12), A1667-A1670.

20 St-Pierre, J., Wilkinson, D. P., Knights, S., and Bos, M. Relationship between water management, contamination and lifetime degradation in PEFC. J. New Mater. Electrochem. Syst. 2000, 3, 99-106.

21 Mohtadi, R., Lee, W.-K., and Van Zee, J. W. Assessing durability of cathodes exposed to common air impurities. J. Power Sources, 2004, 138, 216-225.

22 Moore, J. M., Adcock, P. L., Lakeman, J. B., and Mepsted, G. O. The effect of battlefield contaminants on PEMFC performance. J. Power Sources, 2000, 85, 254-260.

23 Jing, F., Hou, M., Shi, W., Fu, J., Yu, H., Ming, P., and Yi, B. The effect of ambient contamination of PEMFC performance. J. Power Sources, 2007, 166, 172-176.

24 Springer, T. E., Rockward, T., Zawodzinski, T. A., and Gottesfeld, S. Model for polymer electrolyte fuel cell operation on reformate feed. J. Electrochem. Soc., 2001, 148(1), A11-A23.

25 Sishtla, C., Koncar, G., Platon, R., Gamburzev, S., Appleby, A. J., and Velev, O. Performance and endurance of a PEMFC operated with synthetic reformate fuel feed. J. Power Sources, 1998, 71, 249-255.

26 Qi, Z., He, C., and Kaufman, A. Effect of CO in the anode fuel on the performance of PEM fuel cell cathode. J. Power Sources, 2002, 111, 239-274.

27 Rama, P., Chen, R., and Thring, R. A polymer electrolyte fuel cell model with multi-species input. Proc. IMechE, Part A: J. Power and Energy, 2005, 219, 255-271.

28 Liu, P., Logadottir, A., and Norskov, J. K. Modeling the electro-oxidation of $\mathrm{CO}$ and $\mathrm{H} 2 / \mathrm{CO}$ on $\mathrm{Pt}, \mathrm{Ru}, \mathrm{PtRu}$ and Pt3Sn. Electrochim. Acta, 2003, 48, 3731-3742.

29 Isono, T., Suzuki, S., Kaneko, M., Akiyama, Y., Miyake, Y., and Yonezu, I. Development of a highperformance PEFC module operated by reformed gas. J. Power Sources, 2000, 86, 269-273.

30 Si, Y., Jiang, R., Lin, J.-C., Kunz, R., and Fenton, J. M. CO tolerance of carbon-supported platinum-ruthenium catalysts at elevated temperature and atmospheric pressure in a PEM fuel cell. J. Electrochem. Soc., 2004, 151(11), A1820-A1824.

31 Gottesfled, S. and Pafford, J. A new approach to the problem of carbon monoxide poisoning in fuel cells operating at low temperatures. J. Electrochem. Soc., 1988, 135(10), 2651-2652.

32 Adcock, P. A., Pacheco, S. V., Norman, K. M., and Uribe, F. A. Transition metal oxides as reconfigured fuel cell anode catalysts for improved CO tolerance: polarization data. J. Electrochem. Soc., 2005, 152(2), A459-A466.

33 Cheng, X., Shi, Z., Glass, N., Zhang, L., Zhang, J., Song, D., Liu, Z.-S., Wang, H., and Shen, J. A review of PEM hydrogen fuel cell contamination: impacts, mechanisms, and mitigation. J. Power Sources, 2007, 165, 739-756.

34 Marr, C. and Li, X. Composition and performance modelling of catalyst layer in a proton exchange membrane fuel cell. J. Power Sources, 1999, 77, 17-27.
35 Wang, Q., Eikerling, M., Song, D., Liu, Z., Navessin, T., Xie, Z., and Holdcroft, S. Functionally graded cathode catalyst layers for polymer electrolyte fuel cells. Part I: theoretical modelling. J. Electrochem. Soc., 2004, 151(7), A950-A957.

36 Xie,Z., Navessin, T., Shi, K., Chow, R., Wang, Q., Song, D., Andreaus, B., Eikerling, M., Liu, Z., and Holdcroft, S. Functionally graded cathode catalyst layers for polymer electrolyte fuel cells. Part II: experimental study of the effect of nafion distribution. J. Electrochem. Soc., 2005 , 152(6), A1171-A1179.

37 Frost, J. C., Gascoyne, J. M., Hards, G. A., Wilkinson, D. P., and Prater, K. B. Manufacture of electrodes. US Pat. $5702839,1997$.

38 Fuller, T. and Gray, G. Carbon corrosion induced by partial hydrogen coverage. Durability and reliability of low-temperature fuel cells systems. In the 208th ECS Meeting, Los Angeles, CA, 16-21 October 2005, vol. 1(8).

39 Meyers, J. P. and Darling, R. M. Model of carbon corrosion in PEM fuel cells. J. Electrochem. Soc., 2006, 153(8), A1432-A1442.

40 Merzougui, B. and Swathirajan, S. Rotating disk electrode investigations of fuel cell catalyst degradation due to potential cycling in acid electrolyte. J. Electrochem. Soc., 2006, 153(12), A2220-A2226.

41 Stevens, D. A., Hicks, M. T., Haugen, G. M., and Dahn, J. R. Ex situ and in situ stability studies of PEMFC catalysts. effect of carbon type and humidification on degradation of the cathode. J. Electrochem. Soc., 2005, 152(12), A2309-A2315.

42 Xu, H., Song, Y., Kunz, H. R., and Fenton, J. M. Effect of elevated temperature and reduced relative humidity on ORR kinetics for PEM fuel cells. J. Electrochem. Soc., 2005, 152(9), A1828-A1836.

43 Shao, Y., Yon, G., and Shi, P. Durability study of Pt/C and Pt/CNTs catalysts under simulated PEM fuel cell conditions. J. Electrochem. Soc., 2006, 153(6), A1093A1097.

44 Schulze, M., Knori, T., Schneider, A., and Gülzow, E. Degradation of sealings for PEFC test cells during fuel cell operation. J. Power Sources, 2004, 127, 222-229.

45 Zhang, F. Y., Yang, X. G., and Wang, C. Y. Liquid water removal from a polymer electrolyte fuel cell. J. Electrochem. Soc., 2006, 153(2), A225-A232.

46 Maharudrayya, S., Jayanti, S., and Deshpande, A. P. Pressure drop and flow distribution in multiple parallelchannel configurations used in proton-exchange membrane fuel cell stacks. J. Power Sources, 2006, 157, 358-367.

47 Maharudrayya, S., Jayanti, S., and Desphande, A. P. Pressure losses in laminar flow through serpentine channels in fuel cell stacks. J. Power Sources, 2004, 138 $1-13$.

48 Berraras, F., Lozano, A., Valino, L., Marin, C., and Pasau, A. Flow distribution in a bipolar plate of a proton exchange membrane fuel cell: experiments and numerical simulation studies. J. Power Sources, 2005, 144, 54-66.

49 Karvonen, S., Hottinen, T., Saarinen, J., and Himanen, O. Modeling of flow field in polymer electrolyte membrane fuel cell. J. Power Sources, 2006, 161, 876-887. 
50 Shimpalee, S., Greenway, S., and Van Zee, J. W. The impact of channel path length on PEMFC flow-field design. J. Power Sources, 2006, 160, 398-406.

51 Su, A., Weng, F.-B., Hsu, C.-Y., and Chen, Y.-M. Studies on flooding in PEM fuel cell cathode channels. Int. J. Hydrog. Energy 2006, 31, 1031-1039.

52 Trabold, T. A., Owejan, J. P., Jacobson, D. L., Arif, M., and Huffman, P. R. In situ investigation of water transport in an operating PEM fuel cell using neutron radiography: part 1 - experimental method and serpentine flow field results. Int. J. Heat Mass Transf., 2006, 49, 4712-4720.

53 Trabold, T. A., Owejan, J. P., Jacobson, D. L., Arif, M., and Huffman, P. R. In situ investigation of water transport in an operating PEM fuel cell using neutron radiography: part 2 - transient water accumulation in an interdigitated cathode flow field. Int. J. Heat Mass Transf., 2006, 49, 4721-4731.

54 Liu, X., Guo, H., Ye, F., and Ma, C. H. Water flooding and pressure drop characteristics in flow channels of proton exchange membrane fuel cells. Electrochim. Acta 2007, 52, 3607-3614.

55 Yi, J. S. and Nguyen, T. V. Multicomponent transport in porous electrodes of proton exchange membrane fuel cells using the interdigitated gas distributors. J. Electrochem. Soc., 1999, 146(1), 38-45.

56 Yan, W.-M., Yang, C.-H., Soong, C.-Y., Chen, F., and Mei, S.-C. Experimental studies on optimal operating conditions for different flow field designs of PEM fuel cells. J. Power Sources, 2006, 160, 284-292.

57 Grujicic, M., Zhao, C. L., Chittajallu, K. M., and Ocherbeck, J. M. Cathode and interdigitated air distributor geometry optimization in polymer electrolyte membrane (PEM) fuel cells. Mater. Sci. Eng. B, 2004, 108, 241-252.

58 Wang, L. and Liu, H. Performance studies of PEM fuel cells with interdigitated flow fields. J. Power Sources, 2004, 134, 185-196.

59 Cheng, B., Minggao, O., and Baolian, Y. I. Analysis of water management in proton exchange membrane fuel cells. Tsinghua Sci. Technol., 2006, 11 (1), 54-64.

60 Hwang, J. J., Chao, C. H., Ho, W. Y., Chang, C. L., and Wang, D. Y. Effect of flow orientation on thermalelectrochemical transports in a PEM fuel cell. J. Power Sources, 2006, 157, 85-97.

61 Su, A., Weng, F.-B., Hsu, C.-Y., and Chen Y.-M. Studies on flooding in PEM fuel cell cathode channels. Int. J. Hydrog. Energy 2006, 31, 1031-1039.

62 Arati, E., Pinna, M., and Costa, P. Gas-phase masstransfer resistance at PEMFC electrodes. Part 2. Effects of the flow geometry and the related pressure field. J. Power Sources, 2006, 158, 206-212.

63 Hsieh, S.-S., Yang, S.-H., Kuo, J.-K., Huang, C.-F., and Tsai, H.-H. Study of operational parameters on the performance of micro PEMFCs with different flow fields. Energy Convers. Manage., 2006, 47, 1868-1878.

64 Shyam Prasad, K. B., Maharudrayya, S., and Jayanti, S. Flow maldistribution in interdigitated channels used in PEM fuel cells. J. Power Sources, 2006, 159, 595-604.

65 Zou, J., Peng, X.-F., and Yan, W.-M. Dynamic analysis of gas transport in cathode side of PEM fuel cell with interdigitated flow field. J. Power Sources, 2006, 159, 514-523.

66 Yan, W.-M., Mei, S.-C., Soong, C.-Y., Liu, Z.-S., and Song, D. Experimental study on the performance of PEM fuel cells with interdigitated flow channels. J. Power Sources, 2006, 160, 116-122.

67 Yan, W.-M., Chen, C.-Y., Mei, S.-C., Soong, C.-Y., and Chen, F. Effects of operating conditions on cell performance of PEM fuel cells with conventional or interdigitated flow field. J. Power Sources, 2006, 162, 1157-1164.

68 Owejan, J. P., Trabold, T. A., Jacobson, D. L., Baker, D. R., Hussey, D. S., and Arif, M. In situ investigation of water transport in an operating PEM fuel cell using neutron radiography: part 2 - transient water accumulation in an interdigitated cathode flow field. Int. J. Heat Mass Transf., 2006, 49, 4921-4931.

69 Hwang, J. J., Chao, C. H., and Wu, W. Thermal-fluid transports in a five-layer membrane-electrode assembly of a PEM fuel cell. J. Power Sources, 2006, 163, 450-459.

70 Ge, S.-H. and Yi, B.-L. A mathematical model for PEMFC in different flow modes. J. Power Sources, 2003, 142, $1-11$.

71 Hwang, J. J., Chao, C. H., Ho, W. Y., Chang, C. L., and Wang, D. Y. Effect of flow orientation on thermalelectrochemical transports in a PEM fuel cell. J. Power Sources, 2006, 157, 85-97.

72 Lou, G. L., Ju, H., and Wang, C.-Y. Prediction of drywet-dry transition in polymer electrolyte fuel cells. J. Electrochem. Soc., 2007, 154(3), B316-B321.

73 Watanabe, M., Uchida, H., Seki, Y., and Emori, M. Selfhumidifying polymer electrolyte membranes for fuel cells. J. Electrochem. Soc., 1996, 143(12), 3847-3852.

74 Watanabe, M., Uchida, H., and Emori, M. Analysis of self-humidification and suppression of gas crossover in Pt-dispersed polymer electrolyte membranes for fuel cells. J. Electrochem. Soc., 1998, 145(4), 1137-1141.

75 Liu, Y.-H., Yi, B., Shao, Z.-G., Wang, L., Xing, D., and Zhang, H. Pt/CNTs-Nafion reinforced and selfhumidifying composite membrane for PEMFC applications. J. Power Sources, 2007, 163, 807-813.

76 Zhang, Y., Zhang, H., Zhu, X., Gang, L., Bi, C., and Liang, Y. Fabrication and characterisation of a PTFE-reinforced integral composite membrane for self-humidifying PEMFC. J. Power Sources, 2007, 165, 786-792.

77 Watanabe, M. Structure for wetting diaphragm of solid polymer electrolyte electrochemical cell and process of preparing same. US Pat. 5529 855, 1996.

78 Watanabe, M. Fuel cell, electrolytic cell and process of cooling and/or rehumidifying same. US Pat. 5846 668, 1998.

79 Voss, H. H., Wilkinson, D. P., and Watkins, D. S. Method and apparatus for removing water from electrochemical fuel cells. US Pat. 5260 143, 1993.

80 Voss, H. H., Wilkinson, D. P., and Watkins, D. S. Method and apparatus for removing water from electrochemical fuel cells by controlling the temperature and pressure of the reactant streams. US Pat. 5441 819, 1995.

81 Wilkinson, D. P., Voss, H. H., Fletcher, N. J., Johnson, M. C., and Pow, E. G. Electrochemical fuel cell stack 
with concurrent flow of coolant and oxidant streams and countercurrent flow of fuel and oxidant streams. US Pat. 5773 160, 1998.

82 Fletcher, N. J., Chow, C. Y., Pow, E. G., Wozniczka, B. M., Voss, H. H., and Hornburg, G. Electrochemical fuel cell stack with concurrently flowing coolant and oxidant streams. US Pat. 5547 776, 1996.

83 Qi, Z. and Kauffman, A. Improvement of water management by a microporous sublayer for PEM fuel cells. J. Power Sources, 2002, 109, 38-46.

84 Weber, A. Z. and Newman, J. Effects of microporous layers in polymer electrolyte fuel cells. J. Electrochem. Soc., 2005, 152(4), A677-A688.

85 Pasaogullari, U. and Wang, C.-Y. Two-phase transport and the role of micro-porous layer in polymer electrolyte fuel cells. Electrochim. Acta, 2004, 49, 4359-4369.

86 Pasaogullari, U., Wang, C.-Y., and Chen, K. S. Twophase transport in polymer electrolyte fuel cells with bilayer cathode gas diffusion media. J. Electrochem. Soc., 2005, 152(8), A1574-A1582.

87 Gostick, J. T., Fowler, M. W., Ioannidis, M. A., Protzker, M. D., Volfkovich, Y. M., and Sakars, A. Capillary pressure and hydrophilic porosity in gas diffusion layers for polymer electrolyte fuel cells. J. Power Sources, 2006, 156, 375-387.

88 Lin, G. and Van Nguyen, T. Effect of thickness and hydrophobic polymer content of the gas diffusion layer on electrode flooding level in a PEMFC. J. Electrochem. Soc., 2005, 152(1), A1942-A1948.

89 Wang, X. L., Zhang, H. M., Zhang, J. L., Xu, H. F., Tian, Z. Q., Chen, J., Zhong, H. X., Liang, Y. M., and Yi, B. L. Micro-porous layer with composition carbon black for PEM fuel cells. Electrochim. Acta, 2006, 51, 4909-4915.

90 Gurau, V., Bluemle, M. J., De Castro, E. S., Tsou, Y.-M., Zawodzinski, T. A. Jr., and Mann, A. Jr. Characterisation of transport properties in gas diffusion layers for proton exchange membrane fuel cells. Part II: absolute permeability. J. Power Sources, 2006, 160, 1156-1162.

91 Bevers, D., Rogers, R., and von Bradke, M. Examination of the influence of PTFE coating on the properties of carbon papers in polymer electrolyte fuel cells. J. Power Sources, 1996, 63, 193-201.

92 Lim, C. and Wang, C. Y. Effects of hydrophobic polymer content in GDL on power performance of a PEM fuel cell. Electrochim. Acta, 2004, 49, 4149-4156.

93 Thoben, B. and Siebke, A. Influence of different gas diffusion layers on the water management of the PEFC cathode. J. New Mater. Electrochem. Syst., 2004, 7, 13-20.

94 Yan, Q., Toghiani, H., Lee, Y.-W., Liang, K., and Causey, H. Effect of sub-freezing temperatures on a PEM fuel cell performance, startup and fuel cell components. J. Power Sources, 2006, 160, 1242-1250.

95 Bernardi, D. M. and Verbrugge, M. W. Mathematical model of a gas diffusion electrode bonded to a polymer electrolyte. Am. Inst. Chem. Eng., 1991, 37(8), 1151-1163.

96 Bernardi, D. M. and Verbrugge, M. W. A Mathematical model of the solid-polymer-electrolyte fuel cell. J. Electrochem. Soc., 1992, 139(9), 2477-2491.
97 Fowler, M. W., Mann, R. F., Amphlett, J. C., Peppley, B. A., and Roberge, P. R. Incorporation of voltage degradation into a generalised steady state electrochemical model for a PEM fuel cell. J. Power Sources, 2002, 106 274-283.

98 Yin, K.-M. Parametric study of proton-exchangemembrane fuel cell cathode using an agglomerate model. J. Electrochem. Soc., 2005, 152(3), A583-A593.

99 Xie, J., Garzon, F., Zawodzinski, T., and Smith, W. Ionomer degregation in composite MEAs and its effect on polymer electrolyte fuel cell performance. J. Electrochem. Soc., 2004, 151(7), A1084-A1093.

100 Rajalakshmi, N. and Dhathathreyan, K. S. Catalyst layer in PEMFC electrodes - fabrication, characterisation and analysis. Chem. Eng. J., 2007, 129, 31-40.

101 Mao, L. and Wang, C.-Y. Analysis of cold start in polymer electrolyte fuel cells. J. Electrochem. Soc., 2007, 154(2), AB139-B146.

102 Lee, C. and Merida, W. Gas diffusion layer durability under steady-state and freezing conditions. J. Power Sources, 2007, 164, 141-153.

103 Mao, L. and Wang, C.-Y. Analysis of cold start in polymer electrolyte fuel cells. J. Electrochem. Soc., 2007, 154(2), B139-B146.

104 Cho, E. A., Ko, J.-J., Ha, H.Y., Hong, S.-A., Lee, K.-Y., Lim, T.-W., and Oh, I.-H. Efeects of water removal on the performance degradation of PEMFCs repetitively brought to $<0^{\circ}$ C. J. Electrochem. Soc., 2004, 151(5), A661-A665.

105 Hou, J., Yu, H., Zhang, S., Sun, S., Wang, H., Yi, B. and Ming, $\mathbf{P}$. Analysis of PEMFC freeze degradation at $-20^{\circ} \mathrm{C}$ after gas purging. J. Power Sources, 2006, 162, 513-520.

106 Chang, M.-H., Chen, F., and Teng, H.-S. Effects of twophase transport in the cathode gas diffusion layer on the performance of a PEMFC. J. Power Sources, 2006, 160, 268-276.

107 Zhan, Z., Xiao, J., Li, D., Pan, D., and Yuan, R. Effects of porosity distribution variation on the liquid water flux through gas diffusion layers of PEM fuel cells. J. Power Sources, 2006, 160, 1041-1048.

108 Jang, J.-H., Yan, W.-M., and Shih, C.-C. Effects of the gas diffusion-layer parameters on cell performance of PEM fuel cells. J. Power Sources, 2006, 161, 323-332.

109 Eikerling, M. Water management in cathode catalyst layers of PEM fuel cells. J. Electrochem. Soc., 2006, 153(3), E58-E70.

110 Feser, J. P., Prasad, A. K., and Advani, S. G. Experimental characterisation of in-plane permeability of gas diffusion layers. J. Power Sources, 2006, 162, 1226-1231.

111 Ge, J., Higier, A., and Liu, H. Effect of gas diffusion layer compression on PEM fuel cell performance. J. Power Sources, 2006, 159, 922-927.

112 Ihonen, J., Mikkola, M., and Lindbergh, G. Flooding of gas diffusion backing in PEFCs. J. Electrochem. Soc., 2004, 151(8), A1152-A1161.

113 Nitta, I., Hottinen, T., Hilmanen, O., and Mikkola, M. Inhomogeneous compression of PEMFC gas diffusion layer. Part I: experimental. J. Power Sources, 2007, 171, 26-36.

114 Sui, P. C. and Djilali, N. Analysis of coupled electron and mass transport in the gas diffusion layer of a PEM fuel cell. J. Power Sources, 2006, 161, 294-300. 
115 Matsuura, T., Kato, M., and Hori, M. Study on metallic bipolar plate for proton exchange membrane fuel cell. J. Power Sources, 2006, 161, 74-78.

116 Zhou, P., Wu, C. W., and Ma, G. J. Influence of clamping force on the performance of PEMFCs. J. Power Sources, 2007, 163, 874-881.

117 Chang, W. R., Hwang, J. J., Weng, F. B., and Chan, S. H. Effect of clamping pressure on the performance of a PEM fuel cell. J. Power Sources, 2007, 166, 149-154.

118 Escribano, S., Blachot, J.-F., Ethiève, J., Morin, A., and Mosdale, R. Characterisation of PEMFCs gas diffusion layers properties. J. Power Sources, 2006, 156, 8-13.

119 Bazylak, A., Sinton, D., Liu, Z.-S., and Djilali, N. Effects of compression on liquid water transport and microstructure of PEMFC gas distribution layers. J. Power Sources, 2007, 163, 784-792.

120 Tawfik, H., Hung, Y., and Mahajan, D. Metal bipolar plates for PEM fuel cell - a review. J. Power Sources, 2007, 163, 755-767.

121 Greenwood, P., Chen, R., and Thring, R. H. Polyethylene-carbon material for PEM fuel cell bi-polar plates. Proc. IMechE, Part L: J. Materials: Design and Applications, 2008, 222, DOI: 10.1243/14644207JMDA172.

122 Scholta, J., Rohland, B., Trapp, V., and Focken U. Investigations on novel low-cost graphite composite bipolar plates. J. Power Sources, 1999, 84, 231-234.

123 Davies, D. P., Adcock, P. L., Turpin, M., and Rowen, S. J. Stainless steel as a bipolar plate material for solid polymer fuel cells. J. Power Sources, 2000, 86, 237-242.

124 Wang, H., Sweikart, A., and Turner, J. A. Stainless steel as bipolar plate material for polymer electrolyte membrane fuel cells. J. Power Sources, 2003, 115, 243-251.

125 Wang, H. and Turner, J. A. Ferratic stainless steel as bipolar plate material for polymer electrolyte membrane fuel cells. J. Power Sources, 2004, 128, 193-200.

126 Lee, S.-J., Huang, C.-H., Lai, J.-J., and Chen, Y.-P. Corrosion-resistant component for PEM fuel cells. J. Power Sources, 2004, 131, 162-168.

127 Lee, S.-J., Lai, J.-J., and Huang, C.-H. Stainless steel bipolar plates. J. Power Sources, 2005, 145, 362-368.

128 Jayaraj, J., Kim, Y. C., Kim, K. B., Seok, H. K., and Fleury, E. Corrosion studies on Fe-based amorphous alloys in simulated PEM fuel cell environment. Sci. Technol. Adv. Mater., 2005, 6, 282-289.

129 Cho, E. A., Jeon, U.-S., Hong, S.-A., Oh, I.-H., and Kang, S.-G. Performance of a $1 \mathrm{~kW}$-class PEMFC stack using TiN-coated 316 stainless steel bipolar plates. J. Power Sources, 2005, 142, 177-183.

130 Joseph, S., McClure, J. C., Chianelli, R., Pich, P., and Sebastian, P. J. Conducting polymer-coated stainless steel bipolar plates for proton exchange membrane fuel cells (PEMFC). Int. J. Hydrog. Energy, 2005, 30, 1339-1344.

131 Wang, Y. and Northwood, D. O. An investigation into polypyrrole-coated 316L stainless steel as a bipolar plate material for PEM fuel cells. J. Power Sources, 2006, 163, 500-508.

132 Garcia, M. A. L. and Smit, M. A. Study of electrodeposited polypyrrole coatings for the corrosion protection of stainless steel bipolar plates for the PEM fuel cell. J. Power Sources, 2006, 158, 397-402.

133 Silva, R. F., Fracnhi, D., Leone, A., Pilloni, L., Masci, A., and Pozio, A. Surface conductivity and stability of metallic bipolar plate materials for polymer electrolyte fuel cells. Electrochem. Acta, 2006, 51, 3592-3598.

134 Nikam, V. V. and Reddy, R. G. Copper alloy bipolar plates for polymer electrolyte membrane fuel cell. Electrochim. Acta, 2006, 51, 6338-6345.

135 Heinzel, A., Mahlendorf, F., Niemzig, O., and Kreuz, C. Injection moulded low cost bipolar plates for PEM fuel cells. J. Power Sources, 2004, 131, 35-40.

136 Kuan, H.-C., Ma, C.-C. M., Chen, K. H., and Chen, S.-M. Preparation, electrical, mechanical and thermal properties of composite bipolar plate for a fuel cell. J. Power Sources, 2004, 134, 7-17.

137 Kuo, J.-K. and Chen, C.-K. A novel Nylon-6-S316L fiber compound material for injection molded fuel cell bipolar plates. J. Power Sources, 2006, 162, 207-214.

138 Schunk Moulded Bipolar Plate Datasheet, Schunk Kohlenstofftechnik GmbH. Available from http://www.schunk-fuelcells.com/sixcms/media.php/ 1722/08_02e.pdf

139 Eisenhuth Sigracet Bipolar Plate Datasheet, Eisenhuth. Available from http://www.eisenhuth.de/pdf/ SIGRACET_Datenblaetter.pdf

140 Kehr, D., Rin, G., and Banhardt, V. Bipolar plate press device and method for production thereof. Schunk Kohlenstofftechnik GmbH. World Intellectual Property Organisation. Pat. WO03 047 016, 2003.

141 Bipolar plate for fuel cell stacks. SGL Carbon AG. US Pat. 6706 437, 2004.

142 Yen, C.-Y., Liao, S.-H., Lin, Y.-F., Hung, C.-H., Lin, Y.-Y., and Ma, C.-C. M. Preparation and properties of high performance nanocomposite bipolar plate for fuel cell. J. Power Sources, 2006, 162, 309-315.

143 Tricoli, V. Proton and methanol transport in poly(perfluorosulfonate) membranes containing Cs+ and H+ cations. J. Electrochem. Soc., 1998, 145(11), 3798-3801.

144 Samec, Z., Trojanek, A., and Langmaier, J. Diffusion coefficients of alkali metal cations in nafion form ionexchange measurements. J. Electrochem. Soc., 1997, 144(12), 4236-4242.

145 Legras, M., Hirata, Y., Nguyen, Q. T., Langevin, D., and Métayer, M. Sorption and diffusion behaviours of water in Nafion 117 membranes with different counter ions. Desalination, 2002, 147, 351-357.

146 Stenina, I. A., Sistat, P., Rebrov, A. I., Pourcelly, G., Yaroslavstev, A. B. Ion mobility in Nafion-117 membranes. Desalination, 2004, 170, 49-57.

147 Koter, S., Piotrowski, P., and Kerres, J. Comparative investigations of ion-exchange membranes. J. Membr. Sci., 1999, 153, 83-90.

148 Okada, T., Møller-Holst, S., Gorseth, O., and Kjelstrup, S. Transport and equilibrium properties of Nafion membranes with $\mathrm{H}+$ and $\mathrm{Na}+$ ions. J. Electroanal. Chem., 1998, 442, 137-145.

149 Kundu, S., Simon, L. C., Fowler, M., and Grot, S. Mechanical properties of Nafion electrolyte 
membranes under hydrated conditions. Polymer, 2005, 46, 11707-11715.

150 Xie, G. and Okada, T. Water transport behavior in Nafion 117 membranes. J. Electrochem. Soc., 1995, 142(9), 3057-3062.

151 Okada, T., Nakamura, N., Yuasa, M., and Sekine, I. Ion and water transport characteristics in membranes for polymer electrolyte fuel cells containing $\mathrm{H}+$ and $\mathrm{Ca} 2+$ cations. J. Electrochem. Soc., 1997, 144(8), 2744-2750.

152 Shi, M. and Anson, F. C. Dehydration of protonated Nafion coatings induced by cation exchange and monitored by quartz crystal microgravimetry. J. Electroanal. Chem., 1997, 425, 117-123.

153 Kelly, M. J., Falfilek, G., Besenhard, J. O., Kronberger, H., and Nauer, G. E. Contaminant absorption and conductivity in polymer electrolyte membranes. J. Power Sources, 2005, 145, 249-252.

154 Suresh, G., Scinida, Y. M., Pandey, A. K., and Goswami, A. Self-diffusion coefficient of water in Nafion-117 membrane with different monovalent counterions: a radiotracer study. J. Membr. Sci., 2005, 250, 39-45.

155 Pourcelly, G., Oikonomou, A., Gavach, C., and Hurwitz, H. D. Influence of the water content on the kinetics of counter-ion transport in perflourosulphonic membranes. J. Electroanal. Chem., 1990, 287, 43-59.

156 Okada, T., Xie, G., Gorseth, O., Kjelstrup, S., Nakamura, N., and Arimura, T. Ion and water transport characteristics of Nafion membranes as electrolytes. Electrochim. Acta, 1998, 43(24), 3741-3747.

157 Xie, G., and Okada, T. Characteristics of water transport in relation to microscopic structure in Nafion membranes. J. Chem. Soc. Faraday Trans., 1996, 94(4), 663-669.

158 Springer, T. E., Zawodzinski, T. A., and Gottesfeld, S. Polymer electrolyte fuel cell model. J. Electrochem. Soc., 1991, 138, 2334-2342.

159 Xie, G. and Okada, T. Pumping effects in water movement accompanying cation transport across Nafion 117 membranes. Electrochem. Acta, 1996, 41 (9), 1569-1571.

160 Okada, T. Theory for water management in membranes for polymer electrolyte fuel cells. Part 1 . The effect of impurity ions at the anode side on the membrane performances. J. Electroanal. Chem., 1999, 465, 1-17.

161 Okada, T. Theory for water management in membranes for polymer electrolyte fuel cells. Part 2 . The effect of impurity ions at the cathode side on the membrane performances. J. Electroanal. Chem., 1999, 465, 18-29.

162 Casciola, M., Albertu, G., Sganappa, M., and Narducci, R. On the decay of Nafion proton conductivity at high temperature and relative humidity. J. Power Sources, 2006, 162, 141-145.

163 Weber, A. Z. and Newman, J. Transport in polymerelectrolyte membranes; part II. Mathematical model. J. Electrochem. Soc., 2004, 151(2), A311-A325.

164 Hommura, S., Kunisa, Y., Terada, I., and Yoshitake, M. Characterisation of fibril reinforced membranes for fuel cells. J. Fluorine Chem., 2003, 120, 151-155.

165 Liu, Y.-H., Yi, B., Shao, Z.-G., Xing, D., and Zhang, H. Carbon nanotubes reinforced Nafion composite membrane for fuel cell applications. Electrochem. Solid-State Lett., 2006, 9(7), A356-A359.
166 Ahn, S.-Y., Lee, Y.-C., Ha, H. Y., Hong, S.-A., and Oh, I.-H. Properties of the reinforced composite membranes formbed by melt soluble ion conducting polymer resins for PEMFCs. Electrochem. Acta, 2004, 50, 571-575.

167 Zhang, Y., Zhang, H., Zhu, X., Gang, L., Bi, C., and Liang, Y. Fabrication and characterisation of a PTFE-reinforced integral composite membrane for self-humidifying PEMFC. J. Power Sources, 2007, 165, 786-792.

168 Wang, L., Yi, B. L., Zhang, H. M., Liu, Y. H., Xing, D. M., Shao, Z.-G., and Cai, Y. H. Sulfonated polyimide/PTFE reinforced membrane for PEMFCs. J. Power Sources, 2007, 167, 47-52.

169 Tang, Y., Karlsson, A. M., Santare, M. H., Gilbert, M., Cleghorn, S., and Johnson, W. B. An experimental investigation of humidity and temperature effects on the mechanical properties of perfluorsulfonic acid membranes. Mater. Sci. Eng. A, 2006, 425, 297-304.

170 St-Pierre, J. and Jia, N. Successful demonstration of ballard PEMFCS for space shuttle applications. J. New Mater. Electrochem. Syst. 2002, 5, 263-271.

171 Rama, P., Chen, R., and Thring, R. H. Polymer electrolyte fuel cell transport mechanisms: a universal modelling framework from fundamental theory. Proc. IMechE, Part A: J. Power and Energy, 2006, 220, 535-550.

172 Seddiq, M., Khaleghi, H., and Mirzaei, M. Numerical analysis of gas cross-over through the membrane in a proton exchange membrane fuel cell. J. Power Sources, 2006, 161, 371-379.

173 Stanic, V., Braun, J., and Hoberecht, M. Durability of membrane electrode assemblies (MEAs) in PEM fuel cells operated on pure hydrogen and oxygen. Am. Inst. Aeronaut. Astronaut., 2003, 21 (1), 468-475.

174 Hottinen, T., Himanen, O., Karbonen, S., and Nitta, I. Inhomogeneous compression of PEMFC gas diffusion layer. Part II: modeling the effect. J. Power Sources, 2006, doi:10/1016/j.jopsour.2006.10.076.

175 Huang, X., Solasi, R., Zou, Y., Feshler, M., Reifsnider, K., Condit, D., Burlatsky, S., and Madden, T. Mechanical endurance of polymer electrolyte membrane and PEM fuel cell durability. J. Polym. Sci. B Polym. Phys., 2006, 44, 2346-2357.

176 Kusoglu, A., Karlsson, A. M., Santare, M. H., Cleghorn, S., and Johnson, W. B. Mechanical behaviour of fuel cell membranes under humidity cycles and effect of swelling anisotropy on the fatigue stresses. J. Power Sources, 2007, 170, 345-358.

177 Zhang, J., Xie, Z., Zhang, J., Tang, Y., Song, C., Navessin, T., Shi, Z., Song, D., Wang, H., Wilkinson, D. P., Liu, Z.-S., and Holdcroft, S. High temperature PEM fuel cells. J. Power Sources, 2006, 160, 872-891.

178 Kusolgu, A., Karlsson, A. M., Santare, M. H., Cleghorn, S., and Johnson, W. B. Mechanical response of fuel cell membranes subjected to a hygro-thermal cycle. J. Power Sources, 2006, 161, 987-996.

179 Liu, D. and Case, S. Durability of proton exchange membrane fuel cells under dynamic testing conditions with cyclic current profile. J. Power Sources, 2006, 162 521-531. 
180 Sadiq Al-Baghdadi, M. A. R. and Shahad Al-Janabi, H. A. K. Prediction of hygro-thermal stress distribution in proton exchange membranes using a threedimensional multi-phase computation fluid dynamics model. Proc. IMechE, Part A: J. Power and Energy, 2007, 221, 941-953.

181 Curtin, D. E., Lousenberg, R. D., Henry, T. J., Tangeman, P. C., and Tisack, M. E. Advanced materials for improved PEMFC performance and life. J. Power Sources, 2004, 131, 41-48.

182 U.S. Department of Energy web site. Manufacturing research \& development of PEM fuel cell systems for transportation applications. Available from http://wwwl.eere.energy.gov/hydrogenandfuelcells/ pdfs/mfg_wkshp_fuelcell.pdf

183 MIL-STD-2164. Environmental stress screening process for electronic equipment, 1985, available from www.weibull.com/knowledge/milhdbk.htm.

184 MIL-STD-2165. Testability program for electronic systems and equipments, 1985, available from www.weibull.com/knowledge/milhdbk.htm.

185 MIL-STD-2035A (SH). Nondestructive testing acceptance criteria, 1991, available from www.weibull.com/ knowledge/milhdbk.htm.

186 Kinumoto, T., Inaba, M., Nakayama, Y., Ogata, K., Umebayashi, R., Taksaka, A., Iriyama, Y., Abe, T., and Ogumi, Z. Durability of perfluorinated ionomer membrane against hydrogen peroxide. J. Power Sources, 2006, 158, 1222-1228.

187 Pianca, M., Barchiesi, E., Esposto, G., and Radice, S. End groups in fluoropolymers. J. Fluorine Chem., 1999, 95, 71-84.

188 Alentiev, A., Kostina, J., and Bondarenko, G. Chemical aging of Nafion: FTIR study. Desalination, 2006, 200, 32-33.

189 Qiao, J., Saito, M., Hayamizu, K., and Okada, T. Degradation of perfluorinated ionomer membranes for PEM fuel cells during processing with $\mathrm{H}_{2} \mathrm{O}_{2}$. J. Electrochem. Soc., 2006, 153(6), A967-A974.

190 Inaba, M., Kinumoto, T., Kiriake, M., Umebayashi, R., Tasks, A., and Ogumi, Z. Gas crossover and membrane degradation in polymer electrolyte fuel cells. Electrochim. Acta 2006, 51, 5746-5753.

191 Liu, W. and Zuckerbrod, D. In situ detection of hydrogen peroxide in PEM fuel cells. J. Electrochem. Soc., 2005, 152(6), A1165-A1170.

192 LaConti, A. B., Hamdan, M., and McDonald, R. C. In Handbook of fuel cells: fundamentals, technology and applications (Eds W. Vielstich, A. Lamm, and H. A. Gaseiger), vol. 3, 2003 (Wiley, New York).

193 Inaba, M. Degradation mechanisms for polymer electrolyte fuel cells. In the 14th International Conference on the Properties of Water and Steam, Kyoto, 2004.

194 Endoh, E., Terazono, S., Widjaja, H., and Takimoto, Y. Degradation study of MEA for PEMFCs under low humidity conditions. Electrochem. Solid-State Lett., 2004, 7(7), A209-A211.

195 Schmidt, T. J., Paulus, U. A., Gasteiger, H. A., and Behm, R. J. The oxygen reduction reaction on a Pt/carbon fuel cell catalyst in the presence of chloring anions. J. Electroanal. Chem., 2001, 508, 41-47.

196 Healy, J., Hayden, C., Xie, T., Olson, K., Waldo, R., Brundage, M., Gasteiger, H., and Abbott, J. Aspects of the chemical degradation of PFSA ionomers used in PEM fuel cells. Fuel Cells, 2005, 5(2), 302-308.

197 Aoki, M., Uchida, H., and Watanabe, M. Novel evaluation method for degradation rate of polymer electrolytes in fuel cells. Electrochem. Commun., 2005, 7, 1434-1438.

198 Mittal, V., Kunz, H. R., and Fenton, J. M. Effect of catalyst properties on membrane degradation rate and the underlying degradation mechanism in PEMFCs. J. Electrochem. Soc., 2006, 153(9), A1755-A1759. 